\title{
Southern Hemisphere atmospheric circulation: impacts on Antarctic climate and reconstructions from Antarctic ice core data
}

\author{
Andrew Russell ${ }^{\star 1}$, Glenn R. McGregor ${ }^{2}$ \\ 1 School of Earth, Atmospheric and Environmental Sciences, University of Manch- \\ ester, M13 9PL, UK. \\ 2 School of Geography, Geology and Environmental Science, University of Auck- \\ land, New Zealand.
}

Received: date / Revised version: date

\begin{abstract}
The atmospheric circulation patterns in the Southern Hemisphere have had a significant impact on the climate of the Antarctic and there is much evidence that these circulation patterns have changed in the recent past. This change is thought to have contributed to the warming trend observed at the Antarctic Peninsula over the last 50 years - one of the largest trends observed in this period on the planet. The trends associated with the continental Antarctic climate are less clear but are likely to be impacted less directly by atmospheric circulation changes. The circulation changes can be put into the context of longer timescales by considering atmospheric circulation reconstructions that have been performed using data from Antarctic ice cores. In this review paper we look at the main body of work examining: Antarctic climate trends; the understanding and impact of atmospheric circulation of the mid- to high-latitudes of the Southern Hemisphere; and the usefulness and reliability of atmospheric circulation reconstructions from Antarctic ice core data. Finally, beyond several of the more quantitative reconstructions, it is deemed that an assessment of their consistency is not possible due to the variety of circulation characteristics that the various reconstructions consider.
\end{abstract}

Key words Palaeoatmospheric reconstructions - Antarctic climate change - glaciochemistry

\footnotetext{
* e-mail: andrew.russell-2@manchester.ac.uk
} 


\section{Introduction}

Ice core records from the Antarctic have been used extensively to interpret past atmospheric temperature changes. The longest of these records cover many thousands of years, indeed the recently drilled core from Dome C (see Figure 1 for the locations referred to in this paper) spans at least 740000 years (EPICA community members, 2004). These palaeoclimatic observations are of great importance in the scientific community's effort to place the current climate in context and to aid predictions of future climate changes; see Jones and Mann (2004) or Mayewski et al. (2009) for recent reviews of this point. Ironically, though, whilst these ice core records cover very long periods, Antarctic meteorological observational records are both sparse and short compared to those from the other continents - see Monaghan and Bromwich (2008) for a detailed discussion of this point. Furthermore, the observational records that are available show that one region, the Antarctic Peninsula, has experienced one of the largest and fastest surface (Hansen et al., 1999; Vaughan et al., 2001, 2003) and upper-level (Turner et al., $2006 a$ ) temperature increases. This is in contrast to the climatic regime of the continental interior, which is less clear; this latter point is well highlighted by the reported widespread cooling claims of Doran et al. (2002) and the subsequent questioning of the statistical techniques employed in that work by Turner et al. (2002). Despite the fact that there are many studies of the Antarctic climate regime, employing various datasets - for example: satellite (Comiso, 2000); re-analysis (Cullather et al., 1997; Marshall, 2000); climate model (Turner et al., 2006b); ice pit (Doran et al., 2002; Bertler et al., 2004); and station data (Jacka et al., 2004; Turner et al., 2005; Gillett et al., 2006) — it is difficult to glean a consistent perspective of continental Antarctic temperature changes (Chapman and Walsh, 2007). Recently, however, Steig et al. (2009) have shown that positive temperature trends have occurred over most of the Antarctic since 1957 by employing a statistical reconstruction technique that exploits the high spatial coherence of the Antarctic temperature pattern, which is confirmed by satellite thermal infrared data.

Looking to climate predictions, the Intergovernmental Panel on Climate Change (IPCC) Fourth Assessment Report (AR4) on the physical basis of climate change (IPCC, 2007) have discussed how the lack of reliable observations also makes future projections difficult. However, a study of climate model and re-analysis data (Lynch et al., 2006) has shown a high level of coherence between atmospheric circulation and Antarctic temperature and precipitation anomalies and trends. Similarly, Monaghan et al. (2008) have uncovered some potentially reliable trends within the "warmPeninsula-cold-continent" pattern that often arises in the literature by reconstructing near-surface temperature from multiple sources. Furthermore, Orr et al. (2004) and Marshall et al. (2006) have shown how a circulation regime increasingly dominated by relatively warm, maritime westerlies can explain much of the western Antarctic Peninsula warming, Thomas 


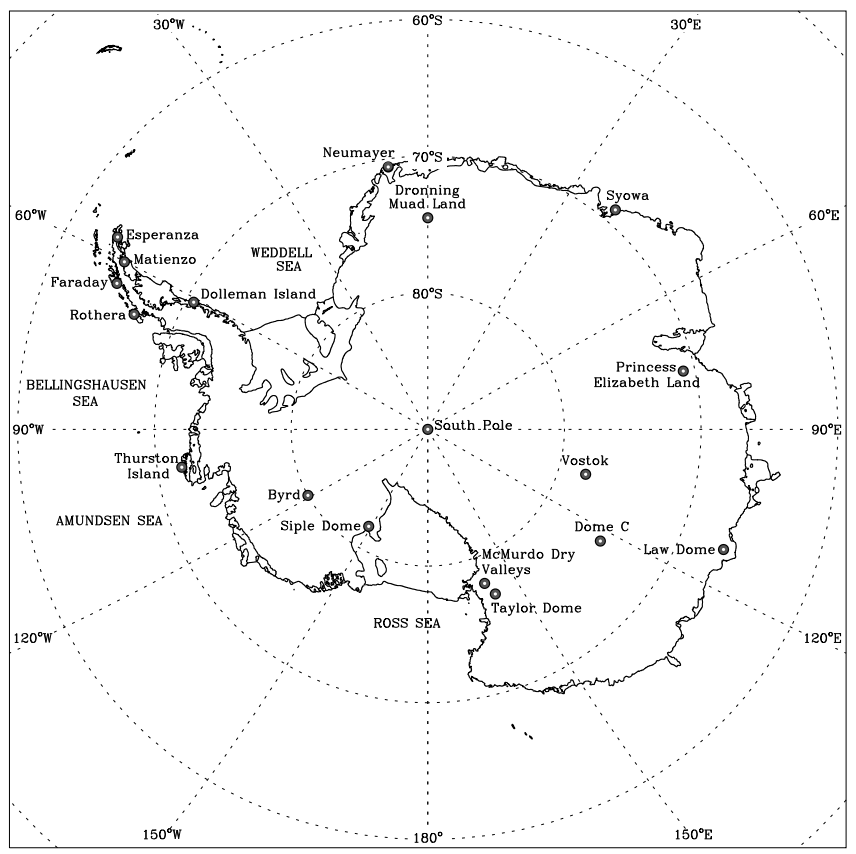

Fig. 1 Map of the Antarctic showing the locations of all the places referred to in the text.

et al. (2008) have uncovered a link between these westerlies and a doubling in snow accumulation in the western Antarctic Peninsula since 1850 and Schneider et al. (2006) have shown an anti-phase relationship between temperature reconstructions from Peninsula and continental ice core sites. This shows that the impact of atmospheric circulation on the Antarctic is of paramount importance.

A particular point of concern with respect to the global climate system is the stability of the Antarctic ice sheets and the ice shelves around the continent. The collapse of the Larsen B ice shelf from the eastern Antarctic Peninsula in 2002 was one such event. Examination of sediment in the vicinity of Larsen $\mathrm{B}$ confirmed that such a break up is unprecedented for the duration of the Holocene (Pudsey and Evans, 2001; Domack et al., 2005). The forcing of the collapse is thought to have been related, in part, to the air temperature changes that occurred above (Rack and Rott, 2004) with the ocean also playing a major role (Shepherd et al., 2003; Glasser and Scambos, 2008). Furthermore, van den Broeke (2005) has shown that atmospheric circulation anomalies (i.e. an increase in north-westerly and north-easterly winds recorded by an AWS on the ice shelf) during the melt season of 2001/2 led to increased surface melting of Larsen B prior to its collapse. This highlights the potential scale of the Southern Hemisphere atmospheric circulation changes on Antarctica and that our understanding of this dynamic region is lacking and in urgent need of clarification. This 
is particularly so given that the Weddell Sea is a very important region of downwelling in the thermohaline circulation and alteration of this would have global consequences. It is also suspected that the increasing strength of winds over the Southern Ocean has reduced the uptake of $\mathrm{CO}_{2}$ (Le Quere et al., 2007).

More generally, it is well established that atmospheric circulation changes have an important impact on climate (Trenberth, 1995). It can also be speculated that circulation modifications, which will, in turn, affect precipitation delivery mechanisms, will have an impact on the chemical composition and accumulation of the snow and ice found at Antarctic ice core sites ${ }^{1}$. Therefore, study of the links between atmospheric circulation and ice core data is important for two reasons: it will improve our interpretation of the ice core data; and will increase our understanding of the atmospheric circulation impacts on Antarctic climate. As such, this paper is structured to first give an overview of the mid- to high-latitude Southern Hemisphere atmospheric circulation and its impact on Antarctic climate (Section 2). This focuses mainly on the Peninsula as it is most strongly influenced by atmospheric circulation changes. It is also necessary to understand the glaciochemistry of Antarctic ice cores (Section 3) and the common precipitation sources for the Antarctic (Section 4) in order to comprehend the work discussed later in this paper. We will then review the major works of atmospheric circulation reconstructions from Antarctic ice cores in Section 5. Finally, we will provide a summary and some potential future directions of this emerging and important field of cross-disciplinary research in Section 6 .

\section{Current Understanding of Atmospheric Circulation Patterns}

This section presents an overview of the typical Southern Hemisphere storm tracks and regions of blocking, as well as the important modes that dominate the mid- to high-latitude atmospheric circulation of the Southern Hemisphere. As well as having a strong influence on climate, as discussed in Chapter 3 of the IPCC AR4 (Trenberth et al., 2007), these modes are of interest in the field of circulation reconstructions as their relative strength and/or phase are often responsible for driving changes in atmospheric circulation that are subsequently detectable in ice cores.

\subsection{Storm Tracks}

King and Turner (1997) discuss how the climatology of Southern Hemisphere cyclones represents an interesting example of how improvements in the observational network has led to an evolution of understanding. For example, from data acquired during the International Geophysical Year (IGY;

\footnotetext{
1 This has been investigated and reviewed to a certain degree, from the perspective of isotopic composition, by Masson-Delmotte et al. (2008).
} 
1957/8), van Loon (1965) and Taljaard (1967) agreed that the formation of Southern Hemisphere cyclones generally occurred in the mid-latitudes. They also thought that, after their cyclogenesis, these depressions usually migrated south-eastward towards the pole. This picture was believed to be confirmed via the classification of cloud vortices from early satellite imagery (Streten and Troup, 1973), a method that also suggested that the region south of $60^{\circ} \mathrm{S}$ is dominated by dissipating vortices. Indeed, Taljaard (1967) described the Antarctic coast as a "depression's graveyard". Physick (1981) reinforced this view with his analysis of data collected during the 1979 First GARP (Global Atmospheric Research Programme) Global Experiment (FGGE).

In contrast to these early studies, Jones and Simmonds (1993) applied an automatic cyclone identification scheme to 15 years of Australian Bureau of Meteorology (ABM) synoptic observations and found two mid-latitude branches of cyclone movement from the Tasman Sea area and from around South America. The former of these tends to "merge" with the circumpolar trough (CPT; see region south of $60^{\circ} \mathrm{S}$ in Figure 2) near the Drake Passage. However, Jones and Simmonds (1993) also highlighted a high level of cyclogenesis in the CPT that was not considered to be important until the 1980s when satellite imagery had reached an adequate level of spatial resolution to identify it (King and Turner, 1997). Cyclogenesis at these high latitudes has since been reported by Turner et al. (1998) in their study of Advanced Very High Resolution Radiometer (AVHRR) satellite imagery, particularly over the Bellingshausen Sea and in the lee of the Antarctic Peninsula. Indeed, it is in this region (around $150^{\circ} \mathrm{W}$ ) that we find the "pole of variability" (Connolley, 1997), which has the highest standard deviation of mean sea-level pressure (MSLP) for the entire Southern Hemisphere, and is, therefore, considered of particular importance for atmospheric circulation driven climate variability of the Antarctic.

Sinclair $(1994,1995)$ used a similar method to Jones and Simmonds (1993), but applied it to the European Centre for Medium Range Weather Forecasting (ECMWF) operational analysis (EOP) data for 1980-1986 to study cyclone and cyclogenesis climatologies. The results were similar to Jones and Simmonds' apart from the lack of cyclogenesis in the CPT which Sinclair (1995) attributed to the differing schemes used in the two studies, with Jones and Simmonds (1993) having used the most reliable (Leonard et al., 1999). Furthermore, Sinclair (1994) reported an increase in the number of cyclones detected in the EOP data in 1983. This is, however, a potentially erroneous result as the EOP model changed from a grid-point model to a spectral model at that time: this highlights the limitations of inhomogeneous data and the motivation for re-analysis data (i.e. a re-analysis of observations using a consistent model set-up throughout). Sinclair's reported increase in cyclone numbers was not evident in the subsequent investigation by Simmonds and Keay $(2000 a, b)$ into mean Southern Hemisphere cyclone behaviour and the associated variability as represented by the National Centers for Environmental Prediction-National Center for Atmospheric Re- 


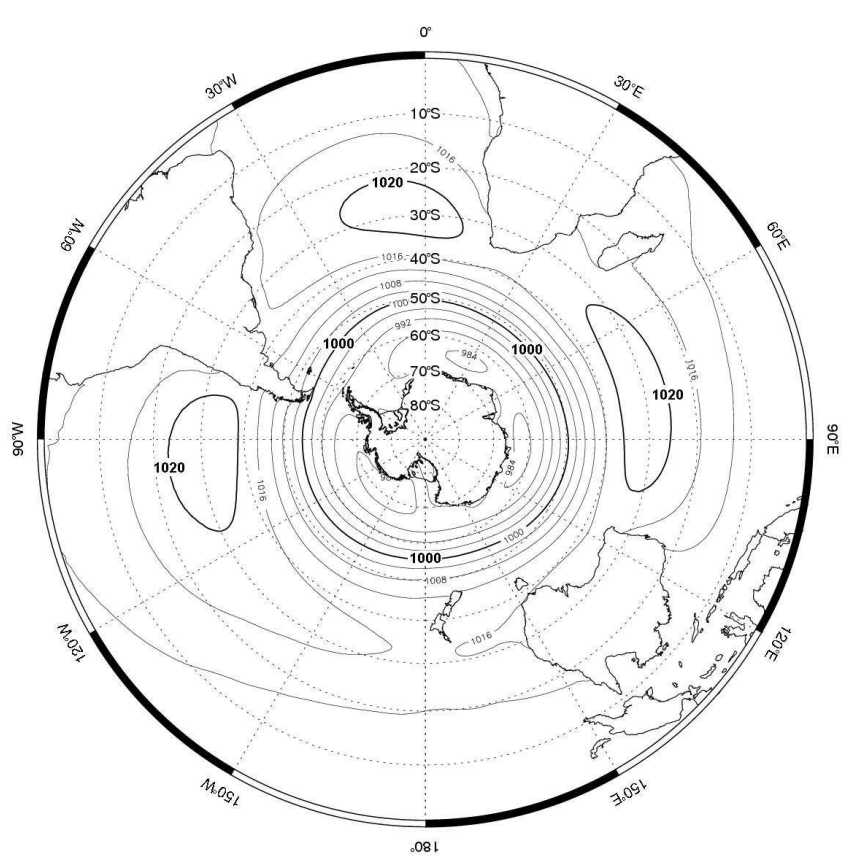

Fig. 2 MSLP climatology for the Southern Hemisphere derived from the European Centre for Medium Range Weather Forecasting (ECMWF) 40-year reanalysis dataset (ERA-40) for the period 1979-2001. Contour interval is $4 \mathrm{hPa}$ and bold contours are used for the $1000 \mathrm{hPa}$ and $1020 \mathrm{hPa}$ contours.

search (NCEP-NCAR) re-analysis (NNR) data (Kalnay et al., 1996) for the period 1958-1997. Simmonds and Keay $(2000 a, b)$ also describe some other interesting features of Southern Hemisphere cyclone behaviour in the NNR, which can be summarised thus:

- cyclone density increased over the eastern Antarctic Peninsula;

- intensity of systems increased over the Weddell Sea;

- cyclogenesis exceeds cyclosis north of $50^{\circ} \mathrm{S}$;

- cyclosis exceeds cyclogenesis south of $50^{\circ} \mathrm{S}$;

- average lifetime of cyclones between $50-70^{\circ} \mathrm{S}$ is 4 days;

- cyclone density generally decreased over the Southern Ocean;

- mean cyclone pressure decreased;

- the combination of these latter two factors (i.e. less frequent but deeper cyclones) resulted in an overall MSLP decrease over the Southern Hemisphere.

While the NNR has facilitated the development of detailed climatologies for the Southern Hemisphere, it must be borne in mind that the NNR initially had some problems associated with the data quality in the high southern latitudes (Hines et al., 2000; Bromwich and Fogt, 2004). Because of this, Simmonds et al. (2003) published a similar analysis to Simmonds and 
Keay $(2000 a, b)$ of the sub-Antarctic region using the NCEP-Department of Energy (NCEP-DOE) re-analysis-2 (NNR-2; Kanamitsu et al. (2002); a reanalysis that attempted to eliminate some of the errors in the original NNR) for the period 1979-2000. The main result of this work, beyond the findings of Simmonds and Keay $(2000 a, b)$, was that a very high level of cyclogenesis was found over the northern Antarctic Peninsula (in both winter and summer) and over the Weddell Sea (mainly in winter). They also report that winter cyclones generally exceed their summer occurrence. Pezza et al. (2007) also note that around Anarctica pressure is generally lower (higher) during a positive (negative) phase of the Pacific Decadal Oscillation (PDO; see Section 2.5) suggesting PDO related moderation of cyclogenesis at the decadal scale.

\subsection{Blocking}

The EOP data has also been used to develop a climatology of Southern Hemisphere anticyclones. For the period 1980-1989, Sinclair (1996) found that the highest density of anticyclones occurred in the latitudinal range of $25-45^{\circ} \mathrm{S}$, which coincides with the sub-tropical high-pressure zone (STHP; see region around $30^{\circ} \mathrm{S}$ in Figure 2). Sinclair (1996) also showed that there is an appreciable number of anticyclones over the Weddell Sea, particularly in summer and early winter. The only other region near the Antarctic coast that experiences a significant occurrence of anticyclones is the Pacific sector. This is of interest as anticyclones in these regions induce an anomalous breakdown in the westerlies which has an impact on the precipitation delivery mechanisms for the western Antarctic and, in particular, the Antarctic Peninsula because of the associated weak westerly flow.

Jones and Simmonds (1994) performed a similar analysis to Sinclair (1996) and found, in 15 years of ABM analyses, that the highest anticyclone density was over the eastern ocean basins at around $25-42^{\circ} \mathrm{S}$. They also found a significant anticorrelation $(\mathrm{r}=-0.6)$ between the Southern Oscillation Index (SOI; see Section 2.5) and the anticyclone density at $120^{\circ} \mathrm{W}$ i.e. near the Amundsen Sea Low (ASL). This implies that a more negative SOI will result in blocking over the Amundsen Sea.

To further highlight the importance of blocking to the Antarctic precipitation regime, Noone et al. (1999) and Masson-Delmotte et al. (2004) have demonstrated mechanisms by which blocking over the Southern Ocean can force significant precipitation events to occur over Dronning Maud Land (DML) and the East Antarctic interior, respectively.

\subsection{The Southern Annular Mode (SAM)}

The SAM (Limpasuvan and Hartmann, 1999) is also known as the Antarctic Oscillation (Gong and Wang, 1999) and the High Latitude Mode (Rogers and van Loon, 1982). In this review, this pattern will only be referred to as 
the SAM. The most widely accepted definition of the SAM is that of Gong and Wang (1999): "the alternation of atmospheric mass between the midlatitude and high-latitude surface pressure". However, the polar vortex that the SAM describes is also present throughout the troposphere and sometimes into the stratosphere. It can be represented as the leading Empirical Orthogonal Function (EOF) of the Southern Hemisphere MSLP - see figure 1 from Gong and Wang (1999). Based on an analysis of the NNR data, Gong and Wang (1999) found that the SAM explains 22.5\% of the Southern Hemisphere MSLP variance. Furthermore, Trenberth et al. (2005) have shown the SAM is responsible for $10 \%$ of the variance of global atmospheric mass transport and Tietäväinen and Vihma (2008) have shown that eastward (northward) moisture transport has a positive (negative) significant, at the $95 \%$ confidence level, correlation with the SAM index at $60^{\circ} \mathrm{S}$.

Gong and Wang (1999) also define a SAM Index based on the difference of the normalised zonal mean pressure between $40^{\circ} \mathrm{S}$ and $65^{\circ} \mathrm{S}$. This definition implies that a more positive SAM index will be associated with stronger circumpolar westerlies, increased cyclonicity and stronger zonal winds. However, the Gong and Wang (1999) index is based on the NNR data which has anomalous pressure trends in the high southern latitudes (Hines et al., 2000). Marshall (2003), on the other hand, has used station data from the Southern Hemisphere at approximately $40^{\circ} \mathrm{S}$ and $65^{\circ} \mathrm{S}$ to present a more reliable SAM index ${ }^{2}$ (Figure 3). There are noticeable differences between the Marshall (2003) and the Gong and Wang (1999) indices, especially in the trends observed. Marshall (2003) found a pronounced positive trend in the 1970s of his index and showed that the overall trend in the NNR SAM index is exaggerated by a factor of two relative to his index. Also, the greatest positive trend in the Marshall SAM index occurred in the summer months whereas the NNR data showed it occurred in winter. Marshall (2002) documented a statistically significant increase in the circumpolar westerlies over the northern Antarctic Peninsula, which is consistent with the trends presented by Marshall (2003). Indeed, the SAM is particularly important to climatic variations observed on the Antarctic Peninsula, as discussed by Marshall (2007), because the Peninsula extends out to much lower latitudes than the rest of the Antarctic. It is, therefore, heavily impacted by the circumpolar vortex and hemispheric westerlies that the Peninsula perpendicularly bisects. Furthermore, van Lipzig et al. (1999) and van den Broeke and van Lipzig (2003) have studied this phenomenon using a relatively high-resolution regional climate model (RCM). They found that the MSLP charts from the model for years with a positive and negative SAM index showed a $90^{\circ}$ change in the direction of the pressure gradient over the Weddell Sea; it was shown that a positive SAM index resulted in isobars perpendicular to the Peninsula and parallel to it for periods with a nega-

2 Jones et al. (2009) have produced a similar, seasonal station-derived SAM index reconstructed back to 1865, calibrated using the Marshall (2003) index, which is due to be published immanently. 


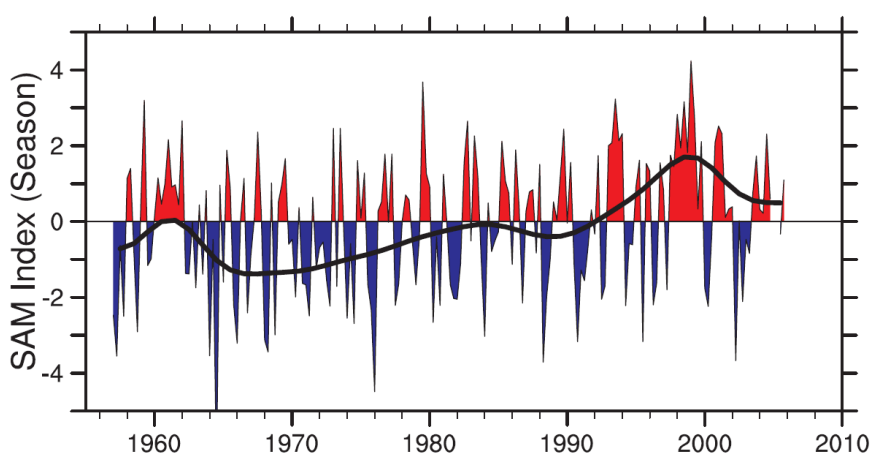

Fig. 3 The seasonal SAM index calculated from station data. The smooth line shows variations of the decadal scale. Source: IPCC (2007) (updated from Marshall (2003)).

tive SAM index. These patterns are similar to the first and second EOFs of Antarctic Peninsula MSLP station data as presented by King (1994) and, given these points, it seems likely that the SAM exerts a strong influence over the atmospheric circulation in this region. This idea is developed further by van Lipzig et al. (2008) who demonstrate, using a high resolution $\mathrm{RCM}$, that changes in temperature with changes in the SAM are stronger over the eastern AP compared to the western AP because of lee side compressional warming during periods dominated by strong westerly (upwind) flows. It is also of interest that, despite projections showing that the positive SAM trend will continue into the 21st Century, the Peninsula warming is not expected to continue (IPCC, 2007).

There is much evidence for, and debate over, the impact of the SAM on Antarctic climate and its driving force; the major works are summarized here. Thompson and Solomon (2002), for example, believe that the positive trend in the SAM is predominantly responsible for the pattern of circulation and temperature trends that they showed to be present in radiosonde observations. Schneider et al. (2004) have also shown that the leading EOF of Antarctic temperature variability recorded by satellite infrared and passive microwave data correlates well with the SAM, although, there are limitations in this satellite data as the former only operates in clear sky conditions and the latter is influenced by snow and ice variations. Kwok and Comiso (2002b) have suggested that the recent changes in the SAM have led to negative temperature anomalies over the entire Antarctic continent, except for the Peninsula, where positive anomalies are seen. Hurrell and van Loon (1994) have argued that similar — SAM-like - changes in the Semi-annual Oscillation (SAO; see next section) were responsible for the temperature trends observed over the Antarctic and, like Thompson and Solomon (2002), they also point out that these circulation changes have occurred largely in parallel with the ozone depletion in the stratosphere above Antarctica and hypothesise that they are linked. Furthermore, the largest trends in the tropospheric SAM index appear to occur after the lower level 
vortex amplifies into the stratosphere in November of each year (Thompson and Wallace, 2000) and also after the major ozone loses occur in the Southern Hemisphere summer (Thompson et al., 2000). Thus, the proposed coupling of ozone depletion with a positive trend in the SAM index is temporally justifiable on a seasonal timescale as well as the interannual scale, as discussed by Thompson and Solomon (2002).

Gillett and Thompson (2003) attempted to ratify the link between ozone depletion and the positive trend in the SAM by employing an atmospheric model forced solely by stratospheric ozone changes ${ }^{3}$. This method achieves their goal, in that they model similar $500 \mathrm{hPa}$ geopotential height, $925 \mathrm{hPa}$ wind and temperature trends to the observations. However, their inference that ozone depletion is, therefore, the driving force behind recent Southern Hemisphere climate changes is largely unsubstantiated as the simplified model they use shows merely moderate correlation between the two phenomena, but no causality. Hartmann et al. (2000) presented a causal mechanism whereby reduced stratospheric ozone and increased greenhouse gases would lead to a cooler stratosphere, resulting in a greater stratospheric meridional temperature gradient. This would, in turn, lead to a stronger circumpolar vortex via a greater level of vertical shear in the zonal wind; Limpasuvan and Hartmann (1999) have used a CGM to show that this vertical shear occurs at the same time as the variations in the SAM. However, this mechanism was not discussed by Gillett and Thompson (2003).

Although there is an increasing body of research that supports the theory that the recent Southern Hemisphere climate changes have been driven by stratospheric influences, Marshall (2002) and Roscoe et al. (2006) note that much of the warming on the western Antarctic Peninsula occurred before any significant trends in the SAM were observed and are, therefore, unlikely to be linked. Furthermore, Marshall et al. (2004) point out that the trend in the SAM itself began approximately a decade before any ozone loss occurred in the Southern Hemisphere stratosphere. These factors are obviously not consistent with the hypothesis presented by Thompson and Solomon (2002) and other workers.

Marshall et al. (2004) also investigated the influences of natural and anthropogenic forcings on a GCM in order to assess the relative importance of these forcings to the changes in the SAM. Their findings imply that the observed trend in the SAM, despite being unlikely to have been forced solely by internal variations, was consistent with a combined, non-linear interaction of natural and anthropogenic forcings. Indeed, Marshall (2003) had discussed how the tropics could influence the SAM in the Pacific region. This connection has also been considered by Fogt and Bromwich (2006) who found that ENSO is most strongly teleconnected to the Antarctic when it has an in-phase relationship with the SAM, which was the case in the 1990s but less so throughout the 1980s.

3 A similar model experiment had previously been implemented by Sexton (2001) but was later found to include erroneous trends in the ozone data used. 


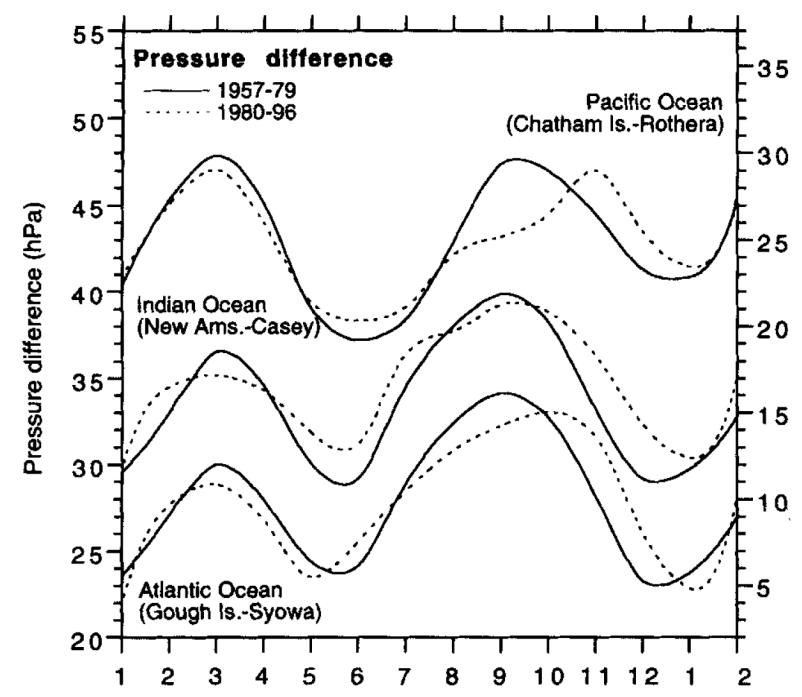

Fig. 4 "Smoothed mean annual cycle of pressure differences between mid-latitude islands and Antarctic coastal stations, for 1957-79 (solid line) and 1980-96 (dashed line). Values for Chatham-Rothera on right axis, for the other two stations pairs on left axis." This plot shows the changing nature of the SAO in the three ocean basins between the two time periods. Source: van den Broeke (1998b).

Despite these contentions, the importance of the SAM in studies of Southern Hemisphere climate variability is still of great importance, as recognised by the IPCC in Chapter 3 (Trenberth et al., 2007). Indeed, a number of independent GCM based analyses have shown that, using scenarios of increasing greenhouse gas and sulphate emissions, Southern Hemisphere climate changes manifest themselves almost exclusively as changes in the SAM (Fyfe et al., 1999; Kushner et al., 2001; Fyfe and Saenko, 2006).

\subsection{The Semi-Annual Oscillation (SAO)}

The SAO represents a twice-yearly expansion and contraction of the CPT, with it being deepest and furthest south in the equinoctial (MAM and SON) seasons (van Loon, 1967) as shown in Figure 4. This pattern occurs as there is a significant difference in the levels of heat storage by the Antarctic and the Southern Ocean; the shift in atmospheric mass described by the SAO resolves to balance this.

The SAO and the SAM describe similar modes of pressure variation in the mid- to high-southern latitudes so it is worth distinguishing them at this stage. The SAO is a reflection of the pattern of the annual cycle of pressure at a certain longitude. In a year when the SAO is strong, two peaks and two troughs (i.e. a $y=\sin (2 x)$ curve) will be clearly seen in the annual pressure 
data. The SAO can, therefore, vary longitudinally around the region that it affects, both in terms of amplitude and phase. The SAM index, on the other hand, is a description of the pressure gradient between $40^{\circ} \mathrm{S}$ and $65^{\circ} \mathrm{S}$. The SAM is a hemispheric indication of the strength of the westerlies, although it also contains longitudinal variability. The data used to calculate this is normalised and will, thus, have had the SAO signal removed.

It has been suggested that the $\mathrm{SAO}$ is responsible for the distribution of warming and cooling trends that have been observed over the Antarctic. For example, by analysing temperature observations, van den Broeke (1998a) reported that a significant portion of the annual variation can be explained by the second harmonic therein i.e. the semi-annual variation associated with the SAO. At Faraday/Vernadsky (western Antarctic Peninsula), almost $80 \%$ of the pressure variance is explained by the second harmonic for the period 1957-1979. For the same period on the eastern Antarctic Peninsula, this drops to $53 \%$ and $37 \%$ for Esperanza and Matienzo, respectively. Further, the amplification of the wavenumber- 3 pattern inherent in the circumpolar circulation (Figure 2) is also proposed to be an important factor for those continental stations that have undergone a cooling.

However, a change has occurred in the SAO (Meehl et al., 1998; van den Broeke, 1998b) meaning that from the late 1970s and into the 1980s, the SAO has undergone a significant weakening, with the second harmonic disappearing in the South Pacific region in the early 1980s (Figure 4). This change manifested itself as a failure of the CPT to expand north in the late spring (Hurrell and van Loon, 1994) leaving a strong polar vortex. This is indicative of a more positive SAM index (van den Broeke, 1998b) and consistent with the trends observed in that mode (Marshall, 2003). This has also led to a dramatic drop in the pressure variance explained by the second harmonic for the period 1980-1996 as reported by van den Broeke (1998b): the figure at Faraday dropped to just 10\% for 1980-1996; and at Esperanza the variance explained changed to $7 \%$. This is obviously a mode of variability that has important links to the climate of the Antarctic, particularly for the western coast of the Peninsula.

\subsection{The El Niño-Southern Oscillation (ENSO)}

ENSO is principally a description of the oceanic and atmospheric conditions over the Pacific. The atmospheric component - the Southern Oscillation (Walker, 1928) - represents the "seesaw" in atmospheric pressure across the Pacific, operating over periods of between two and ten years (Trenberth, 1984). This variability is most often described by the Southern Oscillation Index (SOI), which is used to represent the phase and amplitude of an ENSO event. A negative (positive) SOI indicates a "warm" ("cold") ENSO, or El Niño (La Niña), event. There are other, more regional definitions of El Niño (Trenberth, 1997, for example) but the SOI is most often used in the examples shown below. Over a longer timescale, Quinn and Neal (1992) 
have constructed a useful chronology of El Niño events using data from the logs of sailing vessels that traveled to Ecuador and Peru that indicate ENSO phase. This record starts in 1525 and provides a record for comparison with the atmospheric circulation reconstructions. Garcia et al. (2001) have also performed a similar El Niño reconstruction.

ENSO is teleconnected with the Antarctic climate to a significant degree and these connections have been comprehensively reviewed by Turner (2004). As such, we have simply summarized the major reported ENSO signals found in various Southern Hemisphere high-latitude datasets in Tables 1 and 2. However, of most relevance to the Antarctic beyond those works listed in Tables 1 and 2 is how the ENSO signal is transported poleward by the South Pacific convergence zone (SPCZ). The SPCZ moves north-east relative to its mean position during "cold" (La Niña) events and south-west during "warm" (El Niño) events (Vincent, 1994). This allows the ENSO signal to propagate to the south-eastern Pacific and has been detected as positive height anomalies in the $500 \mathrm{hPa}$ level over the Amundsen and Bellingshausen Seas (Houseago et al., 1998; Renwick, 2005). Given that the western Antarctic and the Peninsula face the area where ENSO has its greatest impact (i.e. the Pacific) this will undoubtedly influence the high latitude atmospheric circulation features that are detectable.

Within these ENSO-Antarctic connections there are certain oceanic, or ocean driven, patterns intrinsically linked to the variability of ENSO, such as the Pacific-South America teleconnections (Mo and Ghil, 1987), the Pacific Decadal Oscillation (Mantua et al., 1997), the Interdecadal Pacific Oscillation (Power et al., 1999) and the Antarctic Dipole (Yuan and Martinson, 2001). These patterns have been noted to exert an influence on the Antarctic climate. Additionally, the Antarctic Circumpolar Wave (ACW) has also been discussed as having a significant impact on the climate of the high southern latitudes in recent years (White and Peterson, 1996). However, the importance and existence of the ACW has been questioned (Connolley, 2002; Park et al., 2004), although, Fischer et al. (2004) believe that they have uncovered an ice core signal from DML showing the ACW over the last 2000 years. Whilst these oceanic patterns do require consideration for a full understanding of Antarctic climate variability, they are deemed to be beyond the scope of this review of atmospheric circulation. This omission is justifiable, given that the re-distribution of energy from the equator to the poles is dominated by atmospheric transport, especially in the highlatitude Southern Hemisphere (Trenberth and Stepaniak, 2003a,b). However, for further details on the impacts of these oceanic factors and their links with atmospheric circulation, the reader is referred to Carleton (2003) and Mayewski et al. (2009).

\subsection{Section summary}

Throughout this section the conflicts in our understanding of the recent/current atmospheric circulation regime in the Southern Hemisphere have been high- 
Table 1 Published links between observations of Antarctic climate and ENSO

\begin{tabular}{|c|c|c|}
\hline Author(s) & Data & ENSO link \\
\hline $\begin{array}{l}\text { Smith and Stearns } \\
(1993)\end{array}$ & $\begin{array}{l}\text { Monthly pressure and } \\
\text { temperature anomalies }\end{array}$ & $\begin{array}{l}\text { Sharp change in sign of temperature and pressure anoma- } \\
\text { lies in year before and after SOI troughs }\end{array}$ \\
\hline Harangozo (2000) & $\mathrm{ABM}$ and SIE & $\begin{array}{l}\text { Statistically significant links between SIE and ENSO-like } \\
\text { changes in the meridional circulation }\end{array}$ \\
\hline $\begin{array}{l}\text { Kwok and Comiso } \\
(2002 a, b)\end{array}$ & Satellite observations & $\begin{array}{l}\text { Positive SOI trend since mid-1970s is consistent with re- } \\
\text { treating sea ice around the Pacific sector of the Antarctic }\end{array}$ \\
\hline Ichiyanagi et al. (2002) & $\begin{array}{l}\text { NNR SST and Peninsula } \\
\text { ice core data }\end{array}$ & $\begin{array}{l}\text { SST for equatorial Pacific is significantly negatively cor- } \\
\text { related with Argentine Island } \delta^{18} \mathrm{O}\end{array}$ \\
\hline Schneider et al. (2004) & Satellite observations & $\begin{array}{l}\text { EOF-2 of Antarctic temperature correlates with SOI on } \\
\text { annual timescale. EOF-1 correlates with SAM }\end{array}$ \\
\hline Bertler et al. (2004) & $\begin{array}{l}\text { ERA- } 40 \text { and snow pit } \\
\text { isotope records }\end{array}$ & $\begin{array}{l}\text { ENSO driven circulation patterns over the Ross Sea sup- } \\
\text { presses warming over the McMurdo Dry Valleys }\end{array}$ \\
\hline $\begin{array}{l}\text { Schneider and Noone } \\
(2007)\end{array}$ & $\begin{array}{l}\text { High resolution ice core } \\
\text { data and MSLP observa- } \\
\text { tions }\end{array}$ & $\begin{array}{l}\text { Co-varying signals in the cores (identified by EOF anal- } \\
\text { ysis) are consistent with ENSO and SAM patterns }\end{array}$ \\
\hline $\begin{array}{l}\text { Schneider and } \\
(2008)\end{array}$ & $\begin{array}{l}\text { Isotope data from West } \\
\text { Antarctic ice cores }\end{array}$ & $\begin{array}{l}\text { Extreme positive anomalies in } 1936-45 \text { strongly telecon- } \\
\text { nected to the } 1939-42 \mathrm{El} \text { Niño }\end{array}$ \\
\hline
\end{tabular}

lighted. Whilst many of these issues are being resolved by current research, it should be borne in mind that these conflicting ideas cannot help with efforts to reconstruct past atmospheric circulation.

\section{Ice Core Signal Sources}

To fully comprehend the mechanisms by which chemical signals are deposited and can be retrieved from ice cores, it is necessary to understand the processes of evaporation from the ocean, transportation through the atmosphere, deposition as snow and then the different stages that fallen snow goes through before becoming ice. This considerable topic, however, is chiefly outside the remit of this review; the reader is referred to Legrand and Mayewski (1997) for a comprehensive glaciochemistry review and a more thorough coverage of the brief discussion of chemical sources in ice cores that is presented below. Similarly, ice core dating, via the identification of layers resulting from significant volcanic eruptions, nuclear weapons tests and the annual cycle of chemical and isotopic species within the ice, will not be given much consideration here. Issues relating to the temporal 
Table 2 Published links between Antarctic climate in model data and ENSO

\begin{tabular}{|c|c|c|}
\hline Author(s) & Data & ENSO link \\
\hline Cullather et al. (1996) & $\mathrm{EOP}$ & $\begin{array}{l}\text { Positive correlation between precipitation and SOI pre- } \\
1990 \text {, negative correlation post- } 1990\end{array}$ \\
\hline $\begin{array}{l}\text { Gerreaud and Battisti } \\
\text { (1999) }\end{array}$ & NNR & $\begin{array}{l}\text { Southern Hemisphere SST anomalies associated with } \\
\text { ENSO-like atmospheric circulation anomalies }\end{array}$ \\
\hline Noone et al. (1999) & $\begin{array}{l}\text { ECMWF 15-year re- } \\
\text { analysis (ERA-15) }\end{array}$ & $\begin{array}{l}\text { Synoptic conditions for DML precipitation events showed } \\
\text { ENSO-like variability }\end{array}$ \\
\hline Bromwich et al. (2000) & EOP and ERA-15 & Similar findings to Cullather et al. (1996) \\
\hline Marshall (2000) & ERA-15 & $\begin{array}{l}\text { Small, statistically significant correlation between } \\
\text { Thurston Island precipitation and ENSO }\end{array}$ \\
\hline Genthon et al. (2003) & $\begin{array}{l}\text { NNR, ERA-15, GCM } \\
\text { and Satellite }\end{array}$ & Links between EOF-1 of precipitation data and ENSO \\
\hline $\begin{array}{l}\text { Genthon and Cosme } \\
(2003)\end{array}$ & $\begin{array}{l}\text { ECMWF 40-year re- } \\
\text { analysis (ERA-40) }\end{array}$ & $\begin{array}{l}\text { ENSO signals in Genthon et al. (2003) and ERA- } 40 \text { are } \\
\text { intermittent and unlikely to last far into the future }\end{array}$ \\
\hline Guo et al. (2004) & NNR-2 and ERA-15 & $\begin{array}{l}\text { Negative correlation between ENSO and Antarctic pre- } \\
\text { cipitation for } 120^{\circ} \mathrm{W}-180^{\circ} \text {, positive for } 30^{\circ}-60^{\circ} \mathrm{W}\end{array}$ \\
\hline $\begin{array}{l}\text { Fogt and Bromwich } \\
(2006)\end{array}$ & ERA-40 & $\begin{array}{l}\text { ENSO teleconnections with the South Pacific region are } \\
\text { governed by coupling with the SAM }\end{array}$ \\
\hline
\end{tabular}

resolution of the data (i.e. the number of ice samples analysed and the annual accumulation at the ice core site) are important but cannot be covered here either — see Bradley (1999) for more details on these subjects.

\subsection{Isotopic Data}

Ice cores are often used to reconstruct past air temperature from the accumulated ice, i.e. the temperature at the time that the snow formed. Studying the isotopic ratios of the $\mathrm{H}_{2} \mathrm{O}$ molecules deposited achieves this; a method that was first discussed by Dansgaard (1964). The basis of this method lies with the fact that there is a vapour pressure difference between $\mathrm{H}_{2}{ }^{16} \mathrm{O}$ and the less common isotope, $\mathrm{H}_{2}{ }^{18} \mathrm{O}$. Therefore, water that evaporates from the sea becomes depleted in $\mathrm{H}_{2}{ }^{18} \mathrm{O}$ due to its lower vapour pressure compared to $\mathrm{H}_{2}{ }^{16} \mathrm{O}$. This heavier fraction is also the most likely to be lost via condensation during transport in the atmosphere. Both of these depletion effects will be amplified by a cold moisture source or by the moist air being transported through a cold environment. Subsequently, the amount of ${ }^{18} \mathrm{O}$ in an ice sample can be calculated as a ratio, ${ }^{18} \mathrm{O}:{ }^{16} \mathrm{O}$, and then expressed 
as a delta $(\delta)$ value to give a proxy measure of temperature. This $\delta$ value incorporates a comparison to a standard seawater sample, referred to as the standard mean ocean water (SMOW). The SMOW has its $\delta^{18} \mathrm{O}$ set to equal zero and the $\delta^{18} \mathrm{O}$ value of an ice sample being examined represents the departure from the SMOW $\delta^{18} \mathrm{O}$ value (Bradley, 1999). Similarly, it is possible to calculate a $\delta \mathrm{D}$ (delta deuterium) value as a heavy isotope of hydrogen, ${ }^{2} \mathrm{H}$ or $\mathrm{D}$, is also found in precipitation as HDO. This isotopic variant also has a lower vapour pressure than $\mathrm{H}_{2} \mathrm{O}$ so all of the above regarding $\mathrm{H}_{2}{ }^{18} \mathrm{O}$ can be applied to HDO. Finally, deuterium excess, or $d$, can be defined as $d=\delta \mathrm{D}-8 \times \delta^{18} \mathrm{O}$. This quantity is particularly pertinent in the context of this review as the different behaviour of the isotopes of $\mathrm{H}$ and $\mathrm{O}$ during fractionation allow inferences to be made regarding the moisture source (Schlosser et al., 2008).

\subsection{Chemical Data}

Considering the aim of palaeoatmospheric reconstructions in the Southern Hemisphere, isotopic details are not of considerable interest: any relationships uncovered between atmospheric circulation and $\delta^{18} \mathrm{O}$ (or $\delta \mathrm{D}$ ) cannot be assumed to be stationary during circulation changes as the temperature of the precipitation sources may be different. Of greater interest for tracing precipitation sources in the Antarctic is the information on past atmospheric composition from ice cores. This can be found by analysing air trapped within pores of the ice and the concentration of various watersoluble chemicals and aerosols that were taken up by the cloud droplets. Legrand and Mayewski (1997) considered the typical sources of the chemicals that are often found in ice cores. They discuss how the oceans, combined with the processes of waves and wind, are the major source for species derived from sea salt i.e. sodium $\left(\mathrm{Na}^{+}\right)$, chlorine $\left(\mathrm{Cl}^{-}\right)$and some magnesium $\left(\mathrm{Mg}^{2+}\right)$, calcium $\left(\mathrm{Ca}^{2+}\right)$, sulphate $\left(\mathrm{SO}_{4}{ }^{2-}\right)$ and potassium $\left(\mathrm{K}^{+}\right)$. Continental shelves are the primary source of terrestrial salts in the ice, such as $\mathrm{Mg}$, Ca, carbonate $\left(\mathrm{CO}_{3}{ }^{2-}\right), \mathrm{SO}_{4}$ and aluminosilicates. Their final source category is biogenic and anthropogenic gas emissions, the primary aerosols from which are usually transformed during transport in the atmosphere and are found in ice cores as secondary aerosols: ammonium $\left(\mathrm{NH}_{4}{ }^{+}\right)$; $\mathrm{Cl}$; nitrate $\left(\mathrm{NO}_{3}{ }^{-}\right)$; $\mathrm{SO}_{4}$; methyl sulfonate $\left(\mathrm{CH}_{3} \mathrm{SO}_{3}{ }^{-}\right)$; fluorine $\left(\mathrm{F}^{-}\right)$; methanoate/formate $\left(\mathrm{HCOO}^{-}\right)$; methyl sulphonic acid (MSA); and other organic compounds. The Legrand and Mayewski (1997) scheme considers both Antarctic and Greenland ice cores so not all of these aerosols will be relevant to studies of the Southern Hemisphere. For example, compared to Greenland, there is very little evidence of anthropogenic emissions at the Antarctic. The authors concluded that the major ions that should be detectable at Antarctica are $\mathrm{Na}, \mathrm{Ca}, \mathrm{Mg}, \mathrm{Cl}, \mathrm{NO}_{3}$ and $\mathrm{SO}_{4}$. In addition to these species, it is possible to calculate non-sea-salt sulphate $\left(\mathrm{nssSO}_{4}{ }^{2-}\right)$ by using a relationship between sulphate and chloride (which is assumed to be 
exclusively derived from sea-salt) in ice cores. It is also possible to measure the quantity and particle size of dust that is trapped in ice cores - these factors can also used to infer information about the source of precipitation comprising ice core layers.

Looking specifically at the origins of particular species for the Antarctic, the source of nitrate is a subject of minor contention. Liss et al. (2004) have suggested that it sourced from biogenic activity in the southern ocean. However, Legrand and Delmas (1986), Legrand and Kirchner (1990) and Goodwin et al. (2003) believe that the major source of nitrate is via transport from the stratosphere in the polar vortex. It will be important to consider this disagreement in the interpretation of work presented in the following section. Furthermore, Rankin et al. (2002) and Wolff et al. (2003) have argued that increases in species derived from sea salt in eastern Antarctic Peninsula ice cores are likely to be derived from highly saline "frost flowers" that form on new sea ice and, therefore, are not an indication of increased open water nearby as had previously been suggested (Peel and Mulvaney, 1992, for example). Indeed, Rankin et al. (2004) deem that the interpretation of sea-salt concentrations for all Antarctic and Greenland ice cores need to be revisited - this would affect a significant amount of work, as we will discuss further in Section 5.

\section{Antarctic Precipitation Source Studies}

This section considers work that has attempted to identify the source of precipitation for Antarctica as a whole and for specific sites over the instrumental era. This gives us some important background information for the next section of this review: the consideration of atmospheric circulation reconstructions from Antarctic ice core data. Throughout this section it is worth bearing in mind that Monaghan et al. (2006) have shown that there have been no significant changes in Antarctic snowfall since the IGY.

\subsection{Precipitation source studies considering the Antarctic as a whole}

The ability to establish the sources of Antarctic precipitation is fundamental to identifying and understanding any atmospheric circulation signals that may be found in ice core data. Some of the earliest and most basic studies on this subject analysed the precipitation source for the Antarctic as a whole. For example, Howarth and Rayner (1986) and Peixoto and Oort (1992) both presented the results from water balance studies that suggested the water vapour that reaches the Antarctic as precipitation comes from the approximate region of $8-40^{\circ} \mathrm{S}$. Petit et al. (1991) agreed that the subtropics are an important source of moisture for central and eastern Antarctica from their models of $\delta^{18} \mathrm{O}$ and $\delta \mathrm{D}$ in the Southern Hemisphere. These findings, however, are hard to justify meteorologically given that storms in the Southern Hemisphere are unlikely to reach the Antarctic from north of $40^{\circ} \mathrm{S}$ 
(see Section 2). These source study results are also largely in disagreement with the low resolution GCM $\left(8^{\circ} \times 10^{\circ}\right)$ based findings of Delaygue et al. $(2000 b)$, who reported that moisture from $30-60^{\circ} \mathrm{S}$ plays a significant role in the precipitation climatology of Antarctica as a whole. Bromwich (1988), in a paper summarising southern high-latitude snowfall, importantly notes that sufficient water evaporates in the region bounded by the $62^{\circ} \mathrm{S}$ parallel and the mean sea ice extent (SIE) to account for all of the precipitation that falls over Antarctica. There is obviously a contention here that requires further investigation.

\subsection{Precipitation source studies considering specific Antarctic sites}

Studies from individual sites give a different view, for example, Bromwich and Weaver (1983) investigated the $\delta^{18} \mathrm{O}$ record for 1974 from the coastal station Syowa $\left(69^{\circ} \mathrm{S}, 39^{\circ} \mathrm{E}\right)$. They inferred, from examining the $\delta^{18} \mathrm{O}$ relationship with sea surface temperature (SST) and SIE, that the moisture source was around $55-58^{\circ} \mathrm{S}$. Turner et al. (1995) have examined the precipitation source for the Rothera station, located on the western Antarctic Peninsula: using meteorological observations and satellite imagery for a one year period, they concluded that half of the cyclones that deliver precipitation to Rothera develop south of the $60^{\circ} \mathrm{S}$ parallel. The importance of such understanding is highlighted by Schlosser (1999) who suggested that the variability of the position of the CPT has had a significant effect on the Neumayer $\delta^{18} \mathrm{O}$ record; for the period 1982-1991, the $\delta^{18} \mathrm{O}$ record implied that the temperature varied in the order of $5^{\circ} \mathrm{C}$ whereas the observed variability from the station itself was less than $1^{\circ} \mathrm{C}$. In addition, Noone et al. (1999) studied the signals from atmospheric circulation that could be detected in the accumulation of an Antarctic ice core from DML. They concluded that the glaciological record is connected to global atmospheric circulation characteristics and could, thus, be used as a tool in reconstructing past atmospheric circulation changes. This hypothesis will generally only hold for coastal ice cores sites as these reflect the high variability of the atmospheric circulation in the $\mathrm{CPT}$ much more directly than central Antarctica where the "isotopic thermometer" is more reliable (Delaygue et al., 2000a). Similar to Turner et al. (1995), Marshall et al. (1998) tracked cyclones between $45-135^{\circ} \mathrm{W}$ and south of $50^{\circ} \mathrm{S}$ in the ERA-15 data to compile a climatology of precipitation delivery to the southern Antarctic Peninsula. Of particular interest, given the focus of the following section, they also found that precipitation events delivered by northerlies were detectable in short ice cores from the region due to spikes in the acidity of the snow delivered by those cyclones. McMorrow et al. (2002) successfully applied a similar methodology to identify precipitation event signals in the Law Dome ice core for a number of events during the 1999/2000 austral summer. Elsewhere, Ciais et al. (1995) concluded, from a study of snow deuterium excess data from a South Pole snow pit and a 1-D isotopic model, that the dominant moisture source was $20-40^{\circ} \mathrm{S}$. This result, like those discussed in Section 4.1, 
again seems unsound given the prevailing atmospheric circulation in this region. However, it is not inconceivable when considering the vapour transport across the Southern Oceans; Bromwich (1988) suggests that water balance studies "do not describe the behaviour of moist air parcels, but rather the net effect of water substance change within an atmospheric volume" and a similar observation could be made of $\delta^{18} \mathrm{O}$ studies when they are used to identify precipitation sources. Despite this, Masson-Delmotte et al. (2003) have combined the isotope record for 1934-1992 from Law Dome with an isotope-GCM to interpret the fluctuation therein. This method uncovered an abrupt shift in meridional circulation during the 1970s.

In view of the above, it is suggested that the study of air parcels would prove more fruitful with respect to the aim of identifying precipitation sources for Antarctic ice core sites. In identifying how far back these air parcels should be tracked, it is of note that Simmonds and Keay (2000a) have shown that the average lifetime of depressions around the Antarctic is 3-4 days. Further, Reijmer and van den Broeke (2001) used back trajectories and associated moisture data from the ERA-15 data to conclude that most of the moisture uptake for precipitation at DML in 1998 occurred 3-5 days before the event. These are the only published attempts to identify the location of moisture uptake for Antarctic precipitation events and they imply that the 5 days preceding a precipitation event represents a physically realistic time frame for identifying precipitation sources via atmospheric analyses such as back trajectories.

Reijmer et al. (2002) have analysed air parcel back trajectories, run for 5 days, for a number of ice core sites, mainly from eastern Antarctica. Looking at the mean trajectories associated with "significant" precipitation events, they found that the main moisture sources for all their sites were located in the latitude range of $50-60^{\circ} \mathrm{S}$ from the nearest ocean to the west of the site in question. In a similar back trajectory analysis, Harris (1992) has also demonstrated the dominance of westerlies for air parcels arriving at the South Pole. Simmonds et al. (2003) used back trajectories run for 4-days from two coastal sites at $90^{\circ} \mathrm{W}$ and $90^{\circ} \mathrm{E}$ to show that most air masses originated from the west and from south of $60^{\circ} \mathrm{S}$ and $50^{\circ} \mathrm{S}$ respectively for the two sites, a result that is in agreement with the observations of Turner et al. (1995). Whilst these studies are important for beginning to understand the sources of the precipitation that comprise Antarctic ice cores, they do not examine individual, or categories of, trajectories delivering precipitation to the sites. That said, much of the Antarctic precipitation regime is driven by a rather homogeneous westerly circulation related to the CPT. Taking this into consideration, Russell et al. (2004) analysed ERA-15 driven back trajectories for precipitation events (and over the climatological timescale) at Dolleman Island, eastern Antarctic Peninsula. The accuracy of some of these precipitation bearing back trajectories was also investigated and deemed good via a number of AVHRR image based case studies (Russell et al., 2008). Using cluster analysis to identify distinct precipitation delivery mechanisms from the back trajectories, Russell et al. (2004) uncovered two 


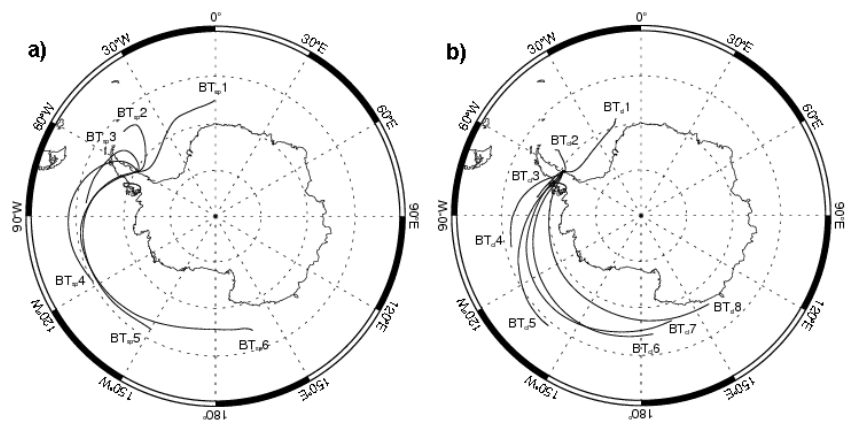

Fig. 5 Composite back trajectory (BT) patterns for the Dolleman Island BTs associated with: a) the significant precipitation events; and b) the BT climatology. The BT patterns have been numbered so that BT1 has the most eastern origin and the highest numbered BT has the most western origin. Source: Russell et al. (2004).

major mechanisms of note (Figure 5). Firstly, they demonstrated that westerlies were prevalent under conditions of a deep circumpolar trough, which, in turn, can be related to a positive SAM index. This is a result that would have been predictable given knowledge of the prevailing atmospheric circulation conditions in this region as discussed above. The second mechanism was related to the southward migration of the South Pacific convergence zone (SPCZ) during El Niño events, which leads to blocking west of the Antarctic Peninsula, thus allowing easterlies to dominate precipitation delivery at Dolleman Island - this is an unusual direction of precipitation delivery for an Antarctic site and occurs due to the interaction of the SPCZ and the physical barrier of the Peninsula. We will discuss later how these precipitation delivery mechanisms can be linked to ice core data.

Over shorter timescales, Helsen et al. (2006) have applied observations, back trajectory analyses, GCM and isotopic modelling to individual precipitation events at DML, which were themselves diagnosed using snow pit data. Their primary findings show that most of the moisture was derived from the southern Atlantic Ocean and that most of the isotopic depletion occurred during the final day of transport. However, this work also highlights the ability to perform such analyses for individual precipitation events and Helsen et al. (2007) have applied a similar method over larger areas of the Antarctic. Schlosser et al. (2008) have looked at $d$ in surface snow in relation to its source, which was identified using back trajectories, and found that the change in moisture source influenced a phase lag between $d$ and $\delta^{18} \mathrm{O}$ which has important implications for ice core climate records reconstructed from isotopic data. Indeed, it is worth emphasising that isotopic composition is sensitive to precipitation source, a subject that has been reviewed by Masson-Delmotte et al. (2008). 


\section{Atmospheric Circulation Reconstructions from Ice Core Data}

In this section we present a largely, though not exclusively, chronological review of atmospheric circulation reconstructions from Antarctic ice core data. Whilst similar work has been performed for the Northern Hemisphere (Mayewski et al., 1994; Appenzeller et al., 1998; Fischer, 2001, for example), we limit our review here to the Southern Hemisphere.

\subsection{Early Reconstructions}

Legrand and Kirchner (1988) published one of the first works specifically identifying atmospheric circulation signals in Antarctic ice core data. They noted that the concentration of $\mathrm{Na}$ (derived from sea-salt) in the winter snow layer of at the South Pole was indicative of meridional transport and that this had weakened since the early 1980s. This result is consistent with a more positive SAM index and weaker SAO, as discussed previously. Furthermore, in the same South Pole ice core Legrand and Feniet-Saigne (1991) found that increases in the record of MSA were concurrent with El Niño events over the period 1922-1984. Whilst these studies demonstrated only a simple correlation between a mode of atmospheric circulation and ice core chemistry, they set in motion the idea that Antarctic ice cores could be used as a tool by which to reconstruct more than just proxy temperature and composition records. Indeed, this train of thought can be traced directly forward to similar work, such as Meyerson et al. (2002) who performed a very similar analysis to Legrand and Feniet-Saigne (1991), again, for MSA in the South Pole ice core. Considering the details of these results, one mechanism often proposed to be the driving force of the MSA-ENSO link is the impact that El Niño has on the SIE around Antarctica. For example, Curran et al. (2003) have shown how the concentration of MSA in an ice core from Law Dome is clearly correlated with SIE in that region. Wolff et al. (2003) agreed with this hypothesis - MSA is derived from DMS, which is released biogenically from the oceans and this link, therefore, appears logical. More recently still, though, Abram et al. (2007) have shown that the MSA-SIE relationship breaks down in the Weddell Sea area of Antarctica - they show that when "cold offshore wind anomalies" dominant they not only increase SIE production but also decrease MSA delivery. If, as has been shown by Harangozo $(2000,2006)$ and Kwok and Comiso (2002a), SIE is itself linked to ENSO related atmospheric circulation anomalies, then this completes the connection between MSA and ENSO. However, there are two points worth bearing in mind: firstly, that Pasteur and Mulvaney $(1999,2000)$ and Curran et al. (2002) have shown that MSA can migrate within ice in both the laboratory and Antarctic ice cores; and secondly, that SIE-ENSO links have been questioned with these unlikely to be consistent around the entire coast of the Antarctic (Carleton, 1989). Indeed, Fundel et al. (2006) examined the extreme MSA years found in a core from DML alongside NNR reanalysis fields, taking into account the potential MSA migration, and found no 
direct link with El Niño events. Nevertheless, they did show that the MSA episodes were likely to be related to the Antarctic Dipole (ADP), which, as described in Section 2.5, is an oceanic phenomenon. This link was made because of the clear 13.9 year MSA period throughout the 2000 year long record - the ADP also has a similar length period. Furthermore, this work showed that the years 1200-1600AD were distinctive because of efficient atmospheric transport, which Fundel et al. (2006) believe is linked with a prominent ADP.

An alternative method of atmospheric circulation reconstruction, pioneered by Peel and Mulvaney (1992), required individual species or groups of species in the ice core data to be linked to specific precipitation delivery mechanisms. They used $\delta^{18} \mathrm{O}, \delta \mathrm{D}, \mathrm{Cl}$ and $\mathrm{nssSO}_{4}$ data from the Dolleman Island ice core for the period 1795-1985 to draw inferences regarding the nature of atmospheric moisture transport paths. Their results, however, could be questioned with respect to one of their assumptions: that increases in sea-salt derived ions, such as chloride $(\mathrm{Cl})$, are an indication of increased open sea. It has since been argued that much of the sea-salt in this region is derived from "frost flowers" that form on new sea ice (see Section 3.2). Despite this, the work still represents an important methodological advance.

Enomoto (1991), on the other hand, discovered significant correlations between accumulation data from South Pole, Dome C and Law Dome and SLP observations from stations located between $40-50^{\circ} \mathrm{S}$. This allowed a reconstruction of SLP for this region to be created for a 100 year window. Spectral analysis of this reconstruction shows a 20-30 year period, which, it was proposed, is due to an oscillation feature of the wave-number zero SLP variation but this could equally be related to the sparseness of the input observations.

\subsection{More recent/advanced reconstructions}

Kreutz et al. (1997) used the assumption that the concentrations of sea salt ions (i.e. $\mathrm{Na}, \mathrm{Mg}, \mathrm{Cl}$ and $\mathrm{K}$ ) are proportional to the level of meridional tropospheric transport. This was used to infer that circulation of this type reaching the Siple Dome core site $\left(149^{\circ} \mathrm{W}, 82^{\circ} \mathrm{S}\right)$ increased around the start of the little ice age (LIA) i.e. around 1400AD. They also believe that circulation conditions similar to those in the LIA have persisted into the 20th Century. Again, this is a very simple but conceptually strong method of inferring past atmospheric circulation characteristics. However, it should be noted that terms like the LIA and the medieval warm period (MWP) are often discussed as being of limited utility due to their temporal and spatial irregularity (Jones and Mann, 2004).

More recently, Goodwin et al. (2004) have found a significant anticorrelation between the "early winter" (i.e. May, June and July) concentration of Na from the Law Dome ice core and SAM related MSLP patterns from the NNR and approximately 60 years of meteorological station data from 


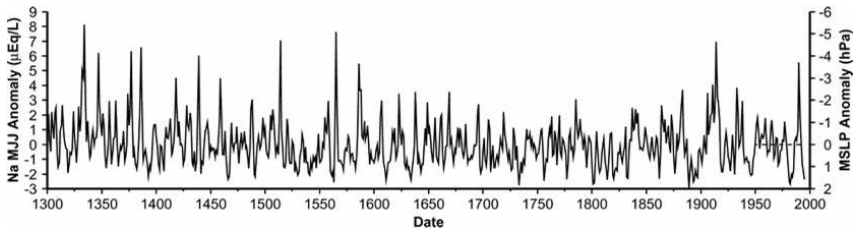

Fig. 6 Anomalies from the 1950-1995 mean (dashed line) of the Na early winter data from Law Dome for 1300-1995. MSLP anomalies for the southwest Pacific region (Campbell Island and Macquarie Island) are shown on the right-hand axis. Source: Goodwin et al. (2004).

the south Indian and south-west Pacific Ocean regions. This Na link is, again, assumed to be driven by changes in meridional transport. From this simple but relatively robust relationship, the authors have reconstructed a well calibrated "early winter" SAM for the last 700 years (Figure 6). Their record shows that the SAM was more negative before 1600AD than it has been during the last 400 years. It also includes the recent positive SAM trend discussed in Section 2. Furthermore, spectral analysis of the proxy SAM shows periods of variability mainly associated with ENSO but also a strong 10.5 year period in the early record and 23 year period in the latter. Whilst discussing possible links to the solar cycle with similar periods of variation, Goodwin et al. (2004) concede that there is no clear evidence to justify such a link.

The reconstruction of such circulation indices is a particularly powerful tool, as also demonstrated by Jones and Widmann $(2003$, 2004) who have produced a SAM index for early summer, reconstructed from Southern Hemisphere tree-ring (1743-2000) and station (1905-2000) data. Tree ring data has limitations (i.e. non-SAM factors cannot be separated out from the data) but both reconstructions capture recent peaks in the index around 1960 and 2000, a period of high variation between 1880-1900 and show that the current SAM trend is not unparalleled over longer time scales.

Kreutz and Mayewski (1999) presented a review of the spatial distribution of glaciochemistry over Antarctica and considered the implications for palaeoatmospheric circulation reconstruction. Their main conclusions regarding the circulation characteristics that are associated with different species were that: nitrate concentration reduces with increased accumulation; $\mathrm{Ca}, \mathrm{K}$ and $\mathrm{Mg}$ are derived from terrestrial dust or exposed bedrock on the Antarctic or South America (indicating either changes in atmospheric circulation to incorporate these features or changes in SIE); and that MSA can be a proxy for SIE (as discussed in Section 5.1), ocean productivity or ENSO. They were also one of the first to perform an EOF analysis on Antarctic ice core data ${ }^{4}$ and uncovered five EOFs of note from the Siple Dome data. They also attempted to assign atmospheric delivery charac-

\footnotetext{
${ }^{4}$ Reusch et al. (1999) also performed an EOF analysis in the same year on a series of cores from near Byrd.
} 
teristics to each of these EOFs, albeit quite basically. The EOF analysis worked particularly well for this ice core and the EOFs show interesting and distinct glaciochemical variability - this is driven largely by changes to the Amundsen Sea Low (ASL) - and they found that the majority of sea-salt is transported to the site in spring ( $\mathrm{SON}$ ), depending on regional circulation strength. This analysis was extended by Kreutz et al. (2000) to include more detailed examination of atmospheric data (EOP) as well as SIE and meteorological station data. They found that MSLP from EOP showed a close relationship with the strength of the ASL, as Kreutz and Mayewski (1999) inferred it would. As, at the time, there was only a 10 year overlap between the ice core data and EOP, Kreutz et al. (2000) used station data from the Australia/New Zealand and South America/Antarctic Peninsula regions to construct a spring trans-polar index (STPI), similar to the TPI of Pittock (1980), back to 1903. This was done so that there was a much longer overlap between the ice core and a representation of ASL for calibration. They found that their EOF1 from the Siple Dome data was significantly, if not strongly $(\mathrm{r}=0.32)$, correlated with the STPI. Therefore, EOF1 was treated as an indicator of Amundsen Sea region MSLP variability over the past 1150 years. This reconstruction displayed periodicities of 3.3 and 3.7 years, which implies a link to ENSO and that this relationship changed during the 1400-1900AD interlude; a similar finding was made by Kreutz et al. (1997). As discussed in Section 2, an anomalously deep ASL is linked with ENSO variability - albeit to temporally changeable degrees (Cullather et al., 1996) — so these findings appear to be sound and justifiable.

A similar method was used by Souney et al. (2002) for a 700 year core from Law Dome, east Antarctica. This study found a dominant EOF that was linked to some characteristic of atmospheric circulation, i.e. that seasalt concentration for the June layer in the core is related to winter circulation "intensity". This led them to conclude that the most intense winter circulation occurred during the 19th Century and the least intense during the 18th Century. Whilst their meteorological analysis does show significant correlations with over half of the June datasets from the 20 Antarctic stations they examined (and some links with meridional pressure gradients from the NNR), these were quite basic analyses. It is also worth noting that these links rely on the sea-salt derived species that dominated their EOF1 and that the origin of sea-salt has been questioned (see Section 3.2). Indeed, Souney et al. (2002) and others (Legrand and Delmas, 1984; Prospero et al., 1991; Whitlow et al., 1992; Mulvaney and Wolff, 1994; Curran et al., 1998; Hall and Wolff, 1998; Kreutz et al., 1998; Wagenbach et al., 1998, for example) all show that sea-salt in ice cores peak in winter when sea-ice growth is at a maximum. Therefore, it appears that the "frost flower" source of sea-salt in ice cores is feasible and that many atmospheric circulation reconstructions should be re-examined, as Rankin et al. (2004) suggest.

Mayewski et al. (2004) examined the Siple Dome ice core data alongside two other Antarctic cores (South Pole and Law Dome). Their analysis 
compared the 700 year Siple Dome record with the two dominant patterns (or EOFs) of Southern Hemisphere atmospheric circulation, as identified by Thompson and Wallace (2000) and Thompson and Solomon (2002). EOF 1 of the $850 \mathrm{hPa}$ pressure field represents the SAM (see Section 2.3) whilst EOF 2 describes a pressure "seesaw" between the South Pacific and Antarctica/South Atlantic. EOF 2 is driven by the ENSO cycle (see Section 2.5) and impacts on the position and strength of the Amundsen Sea Low (ASL). Proxies of SLP from the ice cores show that the period 1700-1850AD departed from the usual pattern seen over the 700 year record studied: they describe a switch from the "out-of-phase alternation of multi-decadal long phases of EOF1 and EOF2 modes of the $850 \mathrm{hPa}$ field" to a lower tropospheric circulation regime characterised by "in-phase behaviour of the of the ASL component of EOF2 and the East Antarctic High component of EOF1" during this period. This obviously has implications for the atmospheric circulation patterns delivering precipitation to these sites and they are also able to discuss a rise in temperature at Siple Dome during the 19th Century and its relationship with an increased frequency of El Niño events penetrating as far south as the pole during this period.

Given that Russell et al. (2004) demonstrated the utility of back trajectories for identifying atmospheric circulation characteristics, Russell et al. (2006) updated this work to using ERA-40 driven back trajectories. As the hydrological cycle in ERA-40 is a significant improvement over that in ERA-15 (Bengtsson et al., 2004), Russell et al. (2006) examined trajectories associated with all precipitation events at Dolleman Island, whereas Russell et al. (2004) examined only "significant" precipitation events to offset a possible overestimation of small events in the ERA-15 data. Back trajectory patterns were then related to the interannual variation of chemical data from the Dolleman Island ice core record. They found that, in particular, the nitrate concentration from the ice core was strongly linked with the ratio of easterly to westerly back trajectories arriving at Dolleman Island, as described by a Cross-Peninsula Index (CPI) defined in the paper, with years dominated by westerlies (easterlies) showing high (low) levels of nitrate in the core. The main explanation for this relationship is that the major source of nitrate in this region is transport from the stratosphere via the circumpolar (westerly) vortex with some input from biogenic sources available during periods of open sea water (see Section 3.2). Conversely, there is no significant easterly source of nitrate, because of the higher SIE to the east of the Peninsula. This atmospheric circulation-nitrate relationship was then used to reconstruct the CPI for the 340-year Dolleman Island ice core record via a regression analysis (Figure 7). Principally, the CPI highlights a period of increased easterlies during 1720-1780AD and an increase in westerlies for 1950-1980AD, the latter concomitant with a positive SAM trend and western Peninsula warming. It is worth noting that there are similarities between the MSLP anomalies presented by Goodwin et al. (2003) and those from Russell et al. (2004) associated with the westerly precipitation delivery mechanisms, thus indicating that similar synoptic patterns led to 


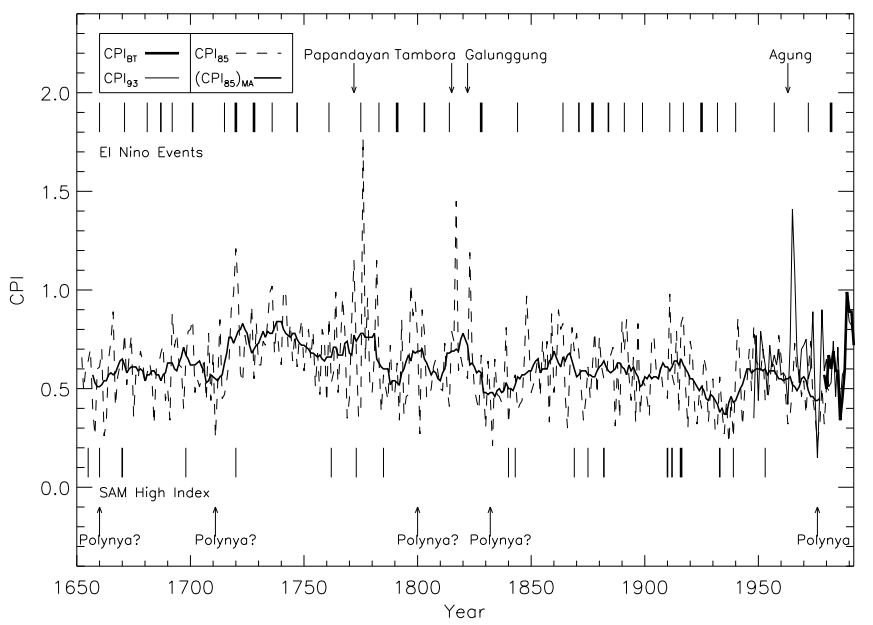

Fig. 7 The Cross-Peninsula Index (CPI) calculated from: a) the frequency of BT patterns $\left(\mathrm{CPI}_{B T}\right.$; heaviest solid line); b) a regression of the 1993 ice core chemical species onto the $\mathrm{CPI}_{B T}\left(\mathrm{CPI}_{93}\right.$; thinnest solid line); and c) the regression equation applied to the chemical species from the 1985 ice core $\left(\mathrm{CPI}_{85}\right.$; dashed line). The medium solid line shows the 10-point moving average of the $\mathrm{CPI}_{85}$. The bars above and below the plot represent the timings of moderate (thin bar), strong (medium bar) or very strong (thick bar) El Niño events (top) and SAM years (bottom). Source: Russell et al. (2006)

the entrainment of nitrate to Dolleman Island and Wilkes Land - the site studied by Goodwin et al. (2003). However, a long calibration was not possible in the Russell et al. (2006) analysis due to a short temporal overlap between the Dolleman Island ice core data (drilled in 1993) and the reliable period of ERA-40 data in the high southern latitudes i.e. from 1979 onwards when satellite data started being assimilated (Bromwich and Fogt, 2004; Dell'Aquila et al., 2007). Furthermore, there are known post-depositional problems relating to the nitrate concentration in ice cores (Mulvaney et al., 1998, for example). This is less of a problem at higher accumulation sites, such as those on the Peninsula, where clear seasonal cycles remain in nitrate profiles and the re-emission of nitrate accounts for a loss of only around a third. Considering this data over the annual timescale, the relative changes year to year will be discernable but there may still be some influence on the reconstructed CPI. Even so, the findings of Russell et al. (2006) are of considerable interest given the very strong correlations over the overlap period: $\mathrm{r}=0.74(-0.75)$ for $\mathrm{NO}_{3}$ concentration versus the frequency of westerlies (easterlies).

Xiao et al. (2004) have analysed a 250 year long ice core from Princess Elizabeth Land and found that EOF1 of the data described the majority of the variability of sea-salt. Furthermore, their EOF1 was also shown to be significantly, negatively correlated with instrumental records of MSLP from two Southern Indian Ocean (SIO) stations and a reconstruction of MSLP 


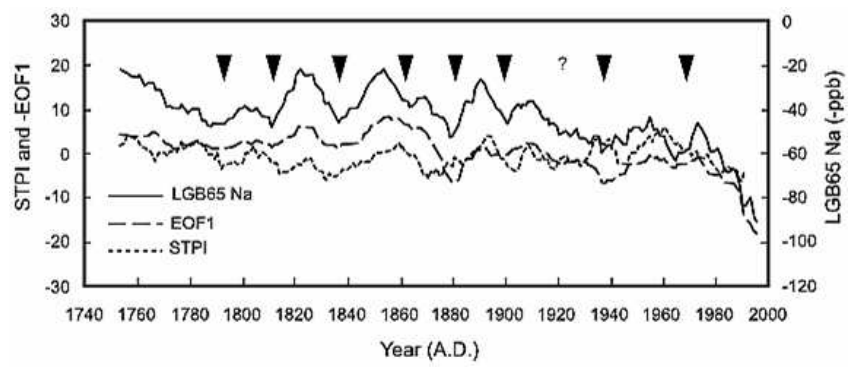

Fig. $8 \mathrm{Na}$ data from the LGB65 ice core (right hand axis, scale reversed) plotted with the reconstructed summer transpolar index (STPI; Villalba et al. (1997)) and the first EOF of the LGB65 data (left hand axis). A 10-year smoothing was applied to all data. The triangles show Na peaks. Source: Xiao et al. (2004).

from sub-Antarctic tree-rings (Villalba et al., 1997). This allowed Xiao et al. (2004) to deduce periods of strong and weak SIO low linked to a shifting of the polar vortex (Figure 8). Given that this variability has an approximately 21 year period, the authors speculate that it is linked with the 22 year solar Hale cycle.

Reusch et al. (1999) have analysed and interpreted a series of 4 short (approximately 40 years of accumulation) ice cores from near Byrd station, west Antarctica, that were separated by only $200 \mathrm{~km}$ in total. Whilst this multisite technique represents an interesting methodological advance, the circulation reconstruction presented in this work was basic: they identified two EOFs of note - marine sea-salt influenced winter air masses and biogenically and stratospherically influenced summer air masses. These mechanisms were shown to be consistent between sites despite average concentration and accumulation not being so. Therefore, over the four sites, the large scale atmospheric circulation delivering precipitation is assumed to be uniform and imposed upon the synoptic and mesoscale spatial variability. Again conducting a multisite analysis, Reusch et al. (2005) used a neural networks technique in order to define transfer functions between synoptic weather patterns (from ERA-15 and AWS data) and annual accumulation and major ion chemistry from the same four relatively short Antarctic ice cores. They present an atmospheric circulation reconstruction from the short ice cores using this method and, despite noise related problems, they believe that the results are acceptable and that neural networks represent a useful tool in the upscaling of ice core data to synoptic conditions.

\subsection{Reconstructions using dust}

The size and concentration of dust particles found in ice cores have also been used on a number of occasions to make inferences regarding atmospheric circulation and climate forcings on a larger scale. Indeed, Fischer et al. (2007) have reviewed the sources, transport, and deposition of dust 
in ice cores over glacial-intergalcial timescales. To give a flavour of such work, we can look to Delmotte et al. (2005) who have uncovered a 200 year oscillation between layers of course and fine dust in two eastern Antarctic Holocene ice cores - Vostok and Dome C - albeit, out of phase for the two cores. The authors justify the assumptions that course dust is derived from the lower and mid-troposphere, fine dust from the upper-troposphere and that the overall mass of dust is an indication of mid- to high-latitude Southern Hemisphere pressure gradient i.e. the SAM. Combining these hypotheses with the observed out of phase oscillations in dust from the cores, Delmotte et al. (2005) believe that this is evidence for a gradual reduction in polar vortex eccentricity, driving an atmospheric circulation dipole over the eastern Antarctic region. It is also speculated that this 200 year mode is related to changes in solar activity. Interestingly, Delmotte et al. (2004) have reported that dust input was constant during the Last Glacial Maximum (LGM), implying a change in atmospheric circulation patterns between the LGM and the Holocene. This conclusion is partly supported by the multi-model climate simulations of Justino and Peltier (2008).

Over longer timescales, Mayewski et al. (1996) have inferred atmospheric circulation change signals during the last deglaciation recorded in an ice core from Taylor Dome. They assumed that the amount of terrestrial dust in the core is related to the "scale" of the atmospheric circulation cell. They concluded that the meridional circulation necessary to carry this dust to Antarctica was not present during the period 10000-14600 years before present. It was also proposed that rapid climate changes had occurred more frequently for the Antarctic than previously thought.

Narcisi et al. (2005), on the other hand, utilized volcanic eruption derived tephra layers from the Dome $\mathrm{C}$ core to conclude that circumpolar westerlies have prevailed in the Southern Hemisphere over the past 200000 years. However, these and similar results (Basile et al., 2001, for example) are potentially of limited use for palaeoatmospheric reconstructions as the data is only available for the irregular instances of volcanic eruptions and are strongly dependant on the eruption strength and location.

\section{Summary and Future Directions}

\subsection{Overview}

In this review we have shown how an understanding of the atmospheric circulation regimes in the Southern Hemisphere benefits our perspective on Antarctic climate change. By combining this with knowledge of ice core data, this has allowed us to not only consider the context of the current Antarctic climate but also to draw conclusions on how atmospheric circulation may have changed over periods longer than observations are available. We have reviewed many of these palaeoatmospheric circulation reconstructions undertaken for the Antarctic; the major findings of which are summarized in Figure 9. Furthermore, comparing Figure 9 with Figure 10, which 


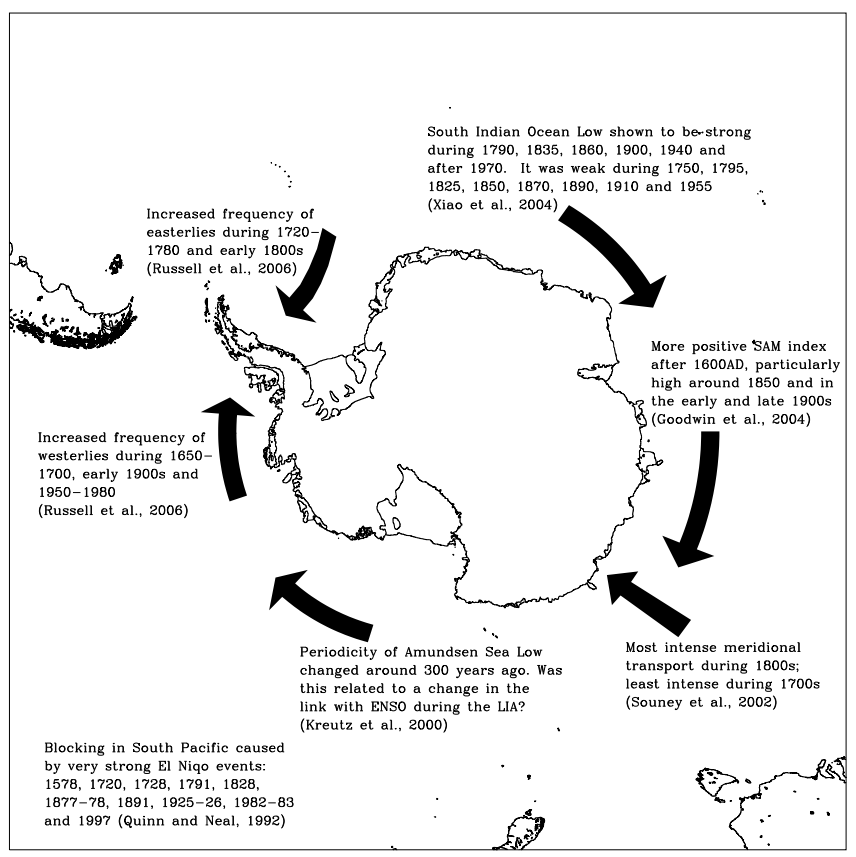

Fig. 9 Summary of the major palaeoatmospheric circulation anomalies as presented in the reconstructions discussed in Section 5.

is a similar summary reproduced from Mayewski et al. (2009), gives an insight into the wider climatic picture that was influencing the atmospheric circulation of the high southern latitudes. However, we also need to consider all the works reviewed here together to see how well they agree with one another.

\subsection{Consistency of the Reconstructions}

Assessing the consistency of the literature reviewed and the associated conclusions concerning reconstructions is not an easy task. Most reconstructions undertaken have employed different methods and, therefore, attempted to re-create different aspects of the circulation. Secondly, the Antarctic is a large landmass that, by virtue of residing over the pole, possesses circumcontinental $\left(360^{\circ}\right)$ atmospheric circulation characteristics. As described in Section 2, these circulation features can vary considerably around the hemisphere. However, the dominance of patterns like the SAM and ENSO may be discernable at geographically different points.

Russell et al. (2006) made an effort to contextualise their reconstruction with a comparison to the extremes from the Marshall (2003), Goodwin et al. (2004) and Quinn and Neal (1992) reconstructions with some success (see Figure 8). With that in mind, how well do the other major reconstructions agree with one another? 
The last 12,000 years

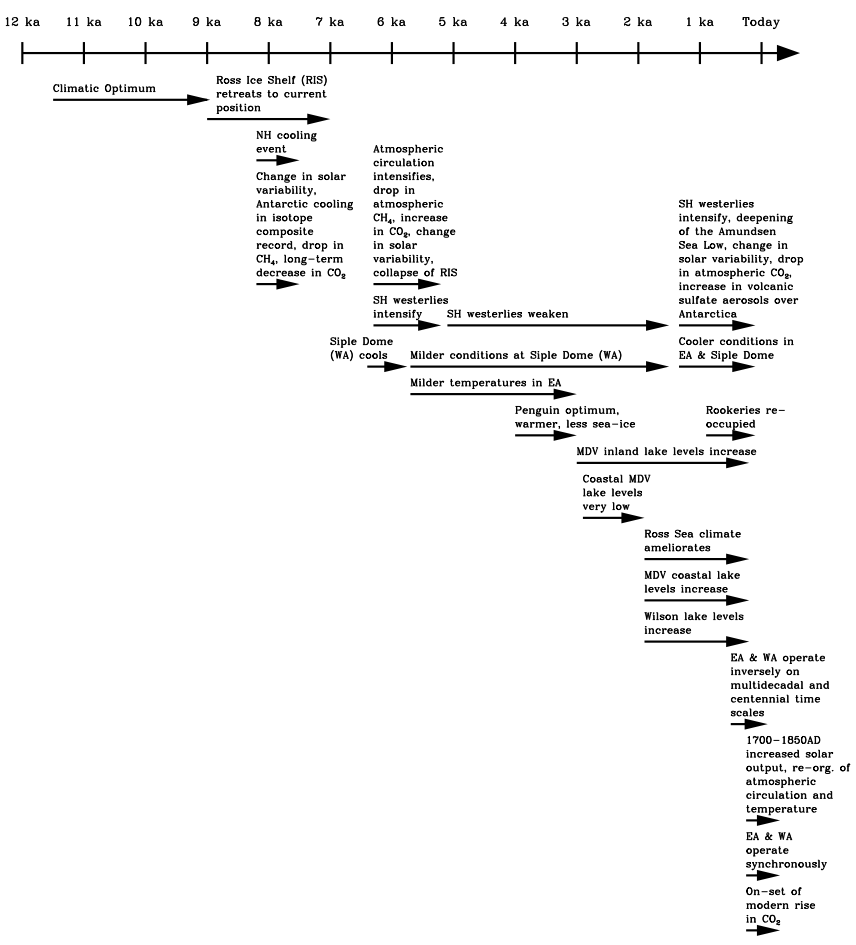

Fig. 10 "Main climatic events of the last 12,000 years: the Antarctic context. NH, Northern Hemisphere; SH, Southern Hemisphere; WA, West Antarctica; EA, East Antarctica; MDV, McMurdo Dry Valleys." The reader is referred to the source paper for details on how this summary was compiled. Source: Mayewski et al. (2009).

As mentioned above, the reconstructions vary in their presentation of results as qualitative or quantitative. This makes their intercomparison troublesome. There appears to be some agreement that Southern Hemisphere atmospheric circulation characteristics were perturbed in some way during the LIA but discussion of what each analysis found is not easy given the often rudimentary meteorological language that is used - this is, of course, often forced by the long timescales that are being considered. Whilst it is disappointing to conclude that a measure of consistency between studies is almost impossible to gauge, this is hopefully something that will become more of a focus in the future as meteorologists and glaciologists work together more closely, as appears to have started to happen recently, particularly with the efforts of the Scientific Committee on Antarctic Research see Mayewski and Goodwin (2008), for example. However, this inconsistent output perhaps also explains why palaeoatmospheric circulation reconstruc- 
tions were almost completely absent from the discussion within the IPCC AR4 (IPCC, 2007).

In this respect it is important to revisit the major questions raised by this review as these in many ways set the context for future research directions. In summary these questions are:

- What are the sources of precipitation for different sites? (Section 4)

- How reliable are the datasets being used to analyse the recent atmospheric circulation? (Section 2)

- How trustworthy are ice core based atmospheric circulation reconstructions when analyses of recent circulation regimes are relatively uncertain? (Section 2)

- What are the mechanisms driving the SAM and how can our understanding of its recent state be improved? (Section 2.3)

- What are the sources of aerosol in the ice? (Section 3.2)

- What is the relationship between MSA, ENSO and SIE? (Section 5.1)

- Is there any evidence of post-depositional migration of species within ice and can such problems be worked with? (Section 5)

- How reliable is ice core data, particularly if we attempt to look at seasonal timescales? (Section 5)

- How can we resolve issues caused by the spatial variability of ice core data? (Section 5)

\subsection{Future Directions}

To significantly advance our understanding of Antarctic precipitation sources a network of ice cores from higher accumulation western Antarctic and Peninsula sites, that receive precipitation from a wide area of sources, needs to be secured. Such multisite cores should be analysed at high resolution in order to allow for seasonal analyses, which are necessary to identify patterns like the SAO within ice core data. It appears from the analysis of Russell et al. (2004) that the eastern Antarctic Peninsula, and its southern extent, are good potential sites for such work. It is also suggested that back trajectory analyses from other sites near the Peninsula should be conducted to find the best region for new work before drilling is initiated. This also raises the issue that most of the ice core data that is currently available is from Eastern Antarctica - a much greater understanding of the Western Antarctica is required and this should be reflected in the planning of future ice core drilling programmes.

Detailed atmospheric circulation analyses for established ice core sites should be performed in order to assess the impact of circulation changes on both the isotopic thermometer for these sites and the potential for reconstructing meteorological characteristics of the precipitation delivery mechanisms. This is starting to become more common in isotopic analyses (Helsen et al., 2007; Masson-Delmotte et al., 2008, for example) but it is important 
that links are established and maintained between the ice core and meteorological communities in order to achieve the most robust and comprehensive results possible from the data that is extracted, at considerable effort, from future and past ice cores. It is also important that the findings of such work are discussed in the context of previous reconstructions, something that has not been a feature of past work, as highlighted in our Section 6.2.

Finally, it is unequivocal that anthropogenic influences on atmospheric composition are changing global climate (IPCC, 2007). However, the nonlinear effects related to circulation changes (Palmer, 1999; Corti et al., 1999, for example) are also of paramount importance, especially in the southern high-latitudes (Marshall et al., 2006). As such, any rigorous circulation reconstructions that can be deduced from palaeoclimatic observations will be of importance in the validation of climate simulations, which are often found wanting in their representation of circulation changes (IPCC, 2007). Modelling studies, such as Fyfe et al. (1999) and Lynch et al. (2006), have already shown important results derived from such changes in circulation - it is important that such work is continued and that palaeoatmospheric circulation reconstructions are used as a valuable context for modelling studies.

Acknowledgements We are grateful to the Natural Environment Research Council's (NERC) British Antarctic Survey (BAS) who provided some financial and computational support for this work. Dr. Gareth J. Marshall and Dr. Rob Mulvaney (BAS) are acknowledged for their helpful comments on earlier drafts of this paper. The anonymous reviewers of this paper also require acknowledgement for their constructive comments. Some of this work was supported by the University of Birmingham via a School of Geography, Earth and Environmental Sciences PhD studentship.

\section{References}

Abram, N. J., R. Mulvaney, E. W. Wolff and M. Mudelsee (2007), 'Ice core records as sea ice proxies: an evaluation from the Weddell Sea region of Antarctica', Journal of Geophysical Research 112, D15101, doi:10.1029/2006JD008139.

Appenzeller, C., T. F. Stocker and M. Anklin (1998), 'North Atlantic Oscillation dynamics recorded in Greenland ice cores', Science 282, 446-449.

Basile, I., J. R. Petit, S. Touron, F. E. Grousset and N. Barkov (2001), 'Volcanic layers in Antarctic (Vostok) ice cores: Source identification and atmospheric implications', Journal of Geophysical Research 106(D23), 31915-31931.

Bengtsson, L., K. I. Hodges and S. Hagemann (2004), 'Sensitivity of largescale atmospheric analyses to humidity observations and its impact on the global water cycle and tropical and extratropical weather systems in ERA40', Tellus 56A, 202-217. 
Bertler, N. A. N., P. J. Barrett, P. A. Mayewski, R. L. Fogt, K. J. Kreutz and J. Shulmeister (2004), 'El Niño suppresses Antarctic warming', Geophysical Research Letters 31, L15207, doi:10.1029/2004GL020749.

Bradley, R. S. (1999), Palaeoclimatology: reconstructing climates of the Quaternary, 2nd edn, Academic Press, San Diego.

Bromwich, D. H. (1988), 'Snowfall in high southern latitudes', Reviews of Geophysics 26, 149-168.

Bromwich, D. H., A. N. Rogers, P. Kallberg, R. I. Cullather, J. W. C. White and K. J. Kreutz (2000), 'ECMWF analyses and reanalyses depiction of ENSO signal in Antarctic precipitation', Journal of Climate 13, 14061420.

Bromwich, D. H. and C. J. Weaver (1983), 'Latitudinal displacement from main moisture source controls $\delta^{18} \mathrm{O}$ of snow in coastal Antarctica', Nature 301, 145-147.

Bromwich, D. H. and R. L. Fogt (2004), 'Strong trends in the skill of the ERA-40 and NCEP/NCAR reanalyses in the high and middle latitudes of the Southern Hemisphere, 1958-2001', Journal of Climate 17, 4603-4619.

Carleton, A. M. (1989), 'Antarctic sea-ice relationships with indices of the atmospheric circulation of the Southern Hemisphere', Climate Dynamics 3, 207-220.

Carleton, A. M. (2003), 'Atmospheric teleconnections involving the Southern Ocean', Journal of Geophysical Research 108(C4), 8080, doi:10.1029/2000JC000379.

Chapman, W. L. and J. E. Walsh (2007), 'A synthesis of Antarctic temperatures', Journal of Climate 20, 4096-4117.

Ciais, P., J. W. C. White, J. Jouzel and J. R. Petit (1995), 'The origin of present-day Antarctic precipitation from surface snow deuterium excess data', Journal of Geophysical Research 100(D9), 18917-18927.

Comiso, J. C. (2000), 'Variability and trends in Antarctic surface temperatures from in situ and satellite infrared measurements', Journal of Climate 13, 1674-1696.

Connolley, W. M. (1997), 'Variability in annual mean circulation in the southern high latitudes', Climate Dynamics 13, 745-756.

Connolley, W. M. (2002), 'Long-term variation of the Antarctic Circumpolar Wave', Journal of Geophysical Research 108(C4), 8076, doi:10.1029/2000JC000380.

Corti, S., F. Molteni and T. N. Palmer (1999), 'Signature of recent climate change in frequencies of natural atmospheric circulation regimes', Nature 398, 799-802.

Cullather, R. I., D. H. Bromwich and M. L. van Woert (1996), 'Interannual variations in the Antarctic precipitation related to El Niño-Southern Oscillation', Journal of Geophysical Research 101(D14), 19109-19118.

Cullather, R. I., D. H. Bromwich and R. W. Grumbine (1997), 'Validation of operational numerical analyses in Antarctic latitudes', Journal of Geophysical Research 102(D12), 13761-13784. 
Curran, M. A. J., A. S. Palmer, T. D. van Ommen, V. I. Morgan, K. L. Phillips, A. J. McMorrow and P. A. Mayewski (2002), 'Post-depositional movement of methanesulphonic acid at Law Dome, Antarctica, and the influence of accumulation rate', Annals of Glaciology 35, 333-339.

Curran, M. A. J., T. D. van Ommen, V. I. Morgan, K. L. Phillips and A. S. Palmer (2003), 'Ice core evidence for Antarctic sea ice decline since the 1950s', Science 302, 1203-1206.

Curran, M. A. J., T. D. van Ommen and V. Morgan (1998), 'Seasonal characteristics of the major ions in the high-accumulation Dome Summit South ice core, Law Dome, Antarctica', Annals of Glaciology 27, 385-390.

Dansgaard, W. (1964), 'Stable isotopes in precipitation', Tellus 16, 436-468.

Delaygue, G., J. Jouzel, V. Masson, R. D. Koster and E. Bard (2000a), 'Validity of the isotopic thermometer in central Antarctica: limited impact of glacial precipitation seasonality and moisture origin', Geophysical Research Letters 27, 2677-2860.

Delaygue, G., V. Masson, J. Jouzel, R. D. Koster and R. J. Healy (2000b), 'The origin of Antarctic precipitation: a modelling approach', Tellus 52B, 19-36.

Dell'Aquila, A., P. M. Ruti, S. Calmanti and V. Lucarini (2007), 'Southern Hemisphere midlatitude atmospheric variability of the NCEP-NCAR and ECMWF reanalyses', Journal of Geophysical Research 112, D08106, doi:10.1029/2006JD007376.

Delmotte, B., J. R. Petit, G. Krinner, V. Maggi, J. Jouzel and R. Udisti (2005), 'Ice core evidence for secular variability and 200-year dipolar oscillations in atmospheric circulation over East Antarctica during the Holocene', Climate Dynamics 24, 641-654.

Delmotte, B., J. R. Petit, K. K. Andersen, I. Basile-Doelseh, V. Maggi and V. Y. Lipenkov (2004), 'Dust size evidence for opposite regional atmospheric circulation changes over east Antarctica during the last climatic transition', Climate Dynamics 23, 427-438.

Domack, E., D. Duran, A. Leventer, S. Ishman, S. Doane, S. McCallum, D. Amblas, J. Ring, R. Gilbert and M. Prentice (2005), 'Stability of the Larsen B ice shelf on the Antarctic Peninsula during the Holocene epoch', Nature 436, 681-685.

Doran, P. T., J. C. Priscu, W. B. Lyons, J. E. Walsh, A. G. Fountain, D. M. McKnight, D. L. Moorhead, R. A. Virginia, D. H. Wall, G. D. Clow, C. H. Fritsen, C. P. McKay and A. N. Parsons (2002), 'Antarctic climate cooling and terrestrial ecosystem response', Nature 415, 517-520.

Enomoto, H. (1991), 'Fluctuations of snow accumulation in the Antarctic and sea level pressure in the Southern Hemisphere in the last 100 years', Climatic Change 18, 67-87.

EPICA community members (2004), 'Eight glacial cycles from an Antarctic ice core', Nature 429, 623-628.

Fischer, H. (2001), 'Imprint of large-scale atmospheric transport patterns on sea-salt records in northern Greenland ice cores', Journal of Geophysical Research 106(D20), 23977-23984. 
Fischer, H., F. Traufetter, H. Oerter, R. Weller and H. Miller (2004), 'Prevalence of the Antarctic Circumpolar Wave over the last two millenia recorded in Dronning Maud Land ice', Geophysical Research Letters 31, L08202, doi:10.1029/2003GL019186.

Fischer, H., M.-L. Siggaard-Andersen, U. Ruth, R. Rthlisberger and E. Wolff (2007), 'Glacial/interglacial changes in mineral dust and sea-salt records in polar ice cores: sources, transport, and deposition', Reviews of Geophysics 45, RG1002, doi:10.1029/2005RG000192.

Fogt, R. L. and D. H. Bromwich (2006), 'Decadal variability of the ENSO teleconnection to the high-latitude South Pacific governed by coupling with the southern annular mode', Journal of Climate 19, 979-997.

Fundel, F., H. Fischer, R. Weller, F. Traufetter, H. Oerter and H. Miller (2006), 'Influence of large-scale teleconnection patterns on methane sulfonate ice core records in Dronning Maud Land', Journal of Geophysical Research 111(D4), D04103, doi:10.1029/2005JD005872.

Fyfe, J. C., G. J. Boer and G. M. Flato (1999), 'The Arctic and Antarctic oscillations and their projected changes under global warming', Geophysical Research Letters 26, 1601-1604.

Fyfe, J. C. and O. A. Saenko (2006), 'Simulated changes in the extratropical southern hemisphere winds and currents', Geophysical Research Letters 33, L06701, doi:10.1029/2005GL025332.

Garcia, R. R., H. F. Diaz, R. G. Herrera, J. Eischeid, M. D. Prieto, E. Hernandez, L. Gimeno, F. R. Duran and A. M. Bascary (2001), 'Atmospheric circulation changes in the tropical Pacific inferred from the voyages of the Manila galleons in the sixteenth-eighteenth centuries', Bulletin of the American Meteorological Society 82, 2435-2455.

Genthon, C. and E. Cosme (2003), 'Intermittent signature of ENSO in west-Antarctic precipitation', Geophysical Research Letters 30, 2081, doi:10.1029/2003GL018280.

Genthon, C., G. Krinner and M. Sacchettini (2003), 'Interannual Antarctic tropospheric circulation and precipitation variability', Climate Dynamics 21, 289-307.

Gerreaud, R. D. and D. S. Battisti (1999), 'Interannual (ENSO) and interdecadal (ENSO-like) variability in the Southern Hemisphere tropospheric circulation', Journal of Climate 12, 2113-2123.

Gillett, N. P. and D. W. J. Thompson (2003), 'Simulation of recent Southern Hemisphere climate change', Science 302, 273-275.

Gillett, N. P., T. D. Kell and P. D. Jones (2006), 'Regional climate impacts of the Southern Annular Mode', Geophysical Research Letters 33, L23704, doi:10.1029/2006GL027721.

Glasser, N. F. and T. A. Scambos (2008), 'A structural glaciological analysis of the 2002 Larsen B ice-shelf collapse', Journal of Glaciology 53, 3-16.

Gong, D. and S. Wang (1999), 'Definition of Antrctic Oscillation Index', Geophysical Research Letters 26, 459-462.

Goodwin, I. D., T. D. van Ommen, M. A. J. Curran and P. A. Mayewski (2004), 'Mid latitude climate variability in the south Indian and south- 
west Pacific regions since 1300 AD', Climate Dynamics 22, 783-794.

Goodwin, I., M. de Angelis, M. Pook and N. W. Young (2003), 'Snow accumulation variability in Wilkes Land, East Antarctica and the relationship to atmospheric ridging in the $130^{\circ}-170^{\circ} \mathrm{E}$ region since 1930 ', Journal of Geophysical Research 108(D21), 4673, doi:10.1029/2002JD002995.

Guo, Z., D. H. Bromwich and K. M. Hines (2004), 'Modeled Antarctic precipitation. Part II: ENSO modulation over west Antarctica', Journal of Climate 17, 448-465.

Hall, J. S. and E. W. Wolff (1998), 'Causes of seasonal and daily variations in aerosol sea-salt concentrations at a coastal Antarctic station', Atmospheric Environment 32, 3669-3677.

Hansen, J., R. Ruedy, J. Glascoe and M. Sato (1999), 'GISS analysis of surface temperature change', Journal of Geophysical Research 104(D24), 30997-31022.

Harangozo, S. A. (2000), 'A search for ENSO teleconnections in the west Antarctic Peninsula climate in Austral winter', International Journal of Climatology 20, 663-679.

Harangozo, S. A. (2006), 'Atmospheric circulation impacts on winter maximum sea ice extent in the west Antarctic Peninsula region (1979-2001)', Geophysical Research Letters 33, L02502, doi:10.1029/2005GL024978.

Harris, J. M. (1992), 'An analysis of 5-day midtropospheric flow patterns for the South Pole: 1985-1989', Tellus 44B, 409-421.

Hartmann, D. L., J. M. Wallace, V. Limpasuvan, D. W. J. Thompson and J. R. Holton (2000), 'Can ozone depletion and global warming interact to produce rapid climate change?', Proceedings of the National Academy of Sciences 97, 1412-1417.

Helsen, M. M., R. S. W. van de Wal and M. R. van den Broeke (2007), 'The isotopic composition of present-day antarctic snow in a lagrangian atmospheric simulation', Journal of Climate 20, 739-756.

Helsen, M. M., R. S. W. van de Wal, M. R. van den Broeke, V. MassonDelmotte, H. A. J. Meijer, M. P. Scheele and M. Werner (2006), 'Modeling the isotopic composition of Antarctic snow using backward trajectories: Simulation of snow pit records', Journal of Geophysical Research 111, D15109, doi:10.1029/2005JD006524.

Hines, K. M., D. H. Bromwich and G. J. Marshall (2000), 'Aritificial surface pressure trends in the NCEP-NCAR reanalysis over the southern ocean and Antarctica', Journal of Climate 13, 3940-3952.

Houseago, R. E., G. R. McGregor, J. C. King and S. A. Harangozo (1998), 'Climate anomaly wave-train patterns linking southern low and high latitudes during south Pacific warm and cold events', International Journal of Climatology 18, 1181-1193.

Howarth, D. A. and J. N. Rayner (1986), Estimates of sources and sinks of atmospheric moisture in the Southern Hemisphere, in 'Second International Conference on Southern Hemisphere Meteorology', American Meteorological Society, Boston, Mass., pp. 163-166. 
Hurrell, J. W. and H. van Loon (1994), 'A modulation of the atmospheric annual cycle in the Southern Hemisphere', Tellus 46A, 325-338.

Ichiyanagi, K., A. Numaguti and K. Kato (2002), 'Interannual variation of stable isotopes in Antarctic precipitation in response to El Niño-Southern Oscillation', Geophysical Research Letters 29, 10.1029/2000GL012815.

IPCC (2007), Climate Change 200\%: The Physical Science Basis. Contribution of Working Group I to the Fourth Assessment Report of the Intergovernmental Panel on Climate Change, [Solomon, S., D. Qin, M. Manning, Z. Chen, M. Marquis, K. B. Averyt, M. Tignor and H. L. Miller (eds.)]. Cambridge University Press, Cambridge, United Kingdom and New York, NY, USA.

Jacka, T. H., W. F. Budd and A. Holder (2004), 'A further assessment of surface temperature changes at stations in the Antarctic and Southern Ocean, 1949-2002', Annals of Glaciology 39, 331-338.

Jones, D. A. and I. H. Simmonds (1993), 'A climatology of Southern Hemisphere extratropical cyclones', Climate Dynamics 9, 131-145.

Jones, D. A. and I. H. Simmonds (1994), 'A climatology of Southern Hemisphere anticyclones', Climate Dynamics 10, 333-348.

Jones, J. M. and M. Widmann (2003), 'Instrument- and tree-ring-based estimates of the Antarctic Oscillation', Journal of Climate 16, 3511-3524.

Jones, J. M. and M. Widmann (2004), 'Early peak in Antarctic Oscillation index', Nature 432, 290-291.

Jones, J. M., R. L. Fogt, M. Widmann, G. J. Marshall, P. D. Jones and M. Visbeck (2009), 'Historical Southern Hemisphere Annular Mode variability. Part I: Century length seasonal reconstructions of the Southern Hemisphere Annular Mode', Journal of Climate 22, in press.

Jones, P.D. and M. E. Mann (2004), 'Climate over past millennia', Reviews of Geophysics 42, RG2002, doi:10.1029/2003RG000143.

Justino, F. and W. R. Peltier (2008), 'Climate anomalies induced by the Arctic and Antarctic Oscillations: Glacial maximum and present-day perspectives', Journal of Climate 21, 459-475.

Kalnay, E., M. Kanamitsu, R. Kistler, W. Collins, D. Deaven, L. Gandin, M. Iredell, S. Saha, G. White, J. Woollen, Y. Zhu, M. Chelliah, W. Ebisuzaki, W. Higgins, J. Janowiak, K. C. Mo, C. Ropelewski, J. Wang, A. Leetmaa, R. Reynolds, R. Jenne and D. Josepth (1996), 'The NCEP/NCAR 40year reanalysis preoject', Bulletin of the American Meteorological Society $\mathbf{7 7}, 437-471$.

Kanamitsu, M., W. Ebisuzaki, J. Woollen, S.-K. Yang, J. J. Hnilo, M. Fiorino and G. L. Potter (2002), 'NCEP-DOE AMIP-II reanalysis (R-2)', Bulletin of the American Meteorological Society 83, 1631-1643.

King, J. C. (1994), 'Recent climatic variability in the vicinity of the Antarctic Peninsula', International Journal of Climatology 14, 357-369.

King, J. C. and J. Turner (1997), Antarctic Meteorology and Climatology, Cambridge University Press, Cambridge.

Kreutz, K. A., P. A. Mayewski, S. Whitlow and M. S. Twickler (1998), 'Limited migration of soluable ionic species in a Siple Dome, Antarctica, 
ice core', Annals of Glaciology 27, 371-377.

Kreutz, K. J. and P. A. Mayewski (1999), 'Spatial variability of Antarctic surface snow glaciochemistry: implications for paleoatmospheric circulation reconstruction', Antarctic Science 11, 105-118.

Kreutz, K. J., P. A. Mayewski, I. I. Pittalwala, L. D. Meeker, M. S. Twickler and S. I. Whitlow (2000), 'Sea level pressure variability in the Amundsen Sea region inferred from a west Antarctic glaciochemical record', Journal of Geophysical Research 105(D3), 4047-4059.

Kreutz, K. J., P. A. Mayewski, L. D. Meeker, M. S. Twickler, S. I. Whitlow and I. I. Pittalwala (1997), 'Bipolar changes in atmospheric circulation during the Little Ice Age', Science 277, 1294-1296.

Kushner, P. J., I. M. Held and T. L. Delworth (2001), 'Southern Hemisphere atmospheric circulation response to global warming', Journal of Climate 14, 2238-2249.

Kwok, R. and J. C. Comiso (2002a), 'Southern ocean climate and sea ice anomalies associated with the Southern Oscillation', Journal of Climate 15, 487-501.

Kwok, R. and J. C. Comiso (2002b), 'Spatial patterns of variability in Antarctic surface temperature: Connections to the Southern Hemisphere Annular Mode and the Southern Oscillation', Geophysical Research Letters 29, doi:10.1029/2002GL015415.

Le Quere, C., C. Rodenbeck, E. T. Buitenhuis, T. J. Conway, R. Langenfelds, A. Gomez, C. Labuschagne, M. Ramonet, T. Nakazawa, N. Metzl, N. Gillett and M. Heimann (2007), 'Saturation of the Southern Ocean $\mathrm{CO}_{2}$ sink due to recent climate change', Science 316, doi: 10.1126/science. 1136188 .

Legrand, M. R. and C. Feniet-Saigne (1991), 'Methanesulfonic acid in south polar snow layers: a record of strong El Niño?', Geophysical Research Letters 18, 187-190.

Legrand, M. R. and P. A. Mayewski (1997), 'Glaciochemistry of polar ice cores: a review', Reviews of Geophysics 35, 219-243.

Legrand, M. R. and R. J. Delmas (1984), 'The ionic balance of Antarctic snow: a 10-year detailed record', Atmospheric Environment 18, 18671874 .

Legrand, M. R. and R. J. Delmas (1986), 'Relative contributions of tropospheric and stratospheric sources to nitrate in Antarctic snow', Tellus 38B, 236-249.

Legrand, M. R. and S. Kirchner (1988), 'Polar atmospheric circulation and chemistry of recent (1957-1983) South Polar precipitation', Geophysical Research Letters 15, 879-882.

Legrand, M. R. and S. Kirchner (1990), 'Origins and variations of nitrate in South Polar precipitation', Journal of Geophysical Research 95, 34933507.

Leonard, S., J. Turner and A. van der Wal (1999), 'An assessment of three automatic depression tracking schemes', Meteoroloical Applications 6, 173-183. 
Limpasuvan, V. and D. L. Hartmann (1999), 'Eddies and the annular mode of climate variability', Geophysical Research Letters 26, 3133-3136.

Liss, P. S., A. L. Chuck, S. M. Turner and A. J. Watson (2004), 'Air-sea gas exchange in Antarctic waters', Antarctic Science 16, 517529.

Lynch, A., P. Uotila and J. J. Cassano (2006), 'Changes in synoptic weather patterns in the polar regions in the twentieth and twenty-first centuries, part 2: Antarctic', International Journal of Climatology 26, 1181-1199.

Mantua, N. J., S. R. Hare, Y. Zhang, J. M. Wallace and R. C. Francis (1997), 'A Pacific interdecadal climate oscillation with impacts on salmon production', Bulletin of the American Meteorological Society 78, 10691079.

Marshall, G. J. (2000), 'An examination of the precipitation regime at Thurston Island, Antarctica, from ECMWF re-analysis data', International Journal of Climatology 20, 255-277.

Marshall, G. J. (2002), 'Analysis of recent circulation and thermal advection change in the northern Antarctic Peninsula', International Journal of Climatology 22, 1557-1567.

Marshall, G. J. (2003), 'Trends in the Southern Annular Mode from observations and reanalyses', Journal of Climate 16, 4134-4143.

Marshall, G. J. (2007), 'Half-century seasonal relationships between the Southern Annular Mode and Antarctic temperatures', International Journal of Climatology 27, 373-383.

Marshall, G. J., A. Orr, N. P. M. van Lipzig and J. C. King (2006), 'The impact of a changing Southern Hemisphere Annular Mode on Antarctic Peninsula summer temperatures', Journal of Climate 19, 5388-5404.

Marshall, G. J., J. Turner and W. D. Miners (1998), 'Interpreting recent accumulation records through an understanding of the regional synoptic climatology: an example from the southern Antarctic Peninsula', Annals of Glaciology 27, 610-616.

Marshall, G. J., P. A. Stott, J. Turner, W. M. Connolley, J. C. King and T. A. Lachlan-Cope (2004), 'Causes of exceptional atmospheric circulation changes in the Southern Hemisphere', Geophysical Research Letters 31, L14205, doi:10.1029/2004GL019952.

Masson-Delmotte, V., B. Stenni and J. Jouzel (2004), 'Common millenialscale variability of Antarctic and Southern Ocean temperatures during the past 5000 years reconstructed from the EPICA Dome C ice core', The Holocene 14, 145-151.

Masson-Delmotte, V., M. Delmotte, V. Morgan, D. Etheridge, T. van Ommen, S. Tartarin and G. Hoffmann (2003), 'Recent southern Indian Ocean climate variability inferred from a Law Dome ice core: new insights for the interpretation of coastal Antarctic isotopic records', Climate Dynamics 21, 153-166.

Masson-Delmotte, V., S. Hou, A. Ekaykin, J. Jouzel, A. Aristarain, R. T. Bernardo, D. Bromwich, O. Cattani, M. Delmotte, S. Falourd, M. Frezzotti, H. Galle, L. Genoni, E. Isaksson, A. Landais, M. Helsen, G. Hoffmann, J. Lopez, V. Morgan, H. Motoyama, D. Noone, H. Oerter, J. R. 
Petit, A. Royer, R. Uemura, G. A. Schmidt ., E. Schlosser, J. C. Simes, E. Steig, B. Stenni, M. Stievenard, M. van den Broeke, R. van de Wal, W.-J. van den Berg, F. Vimeux and J. W. C. White (2008), 'A review of Antarctic surface snow isotopic composition : observations, atmospheric circulation and isotopic modelling', Journal of Climate 21, 3359-3387.

Mayewski, P. A. and I. Goodwin, eds (2008), SCAR report No. 33: ITASE Synthesis Workshop Final Report, Castine, Maine, September 2008, International Council for Science, Paris, France.

Mayewski, P. A., K. A. Maasch, J. W. C. White, E. J. Steig, E. Meyerson, I. Goodwin, V. I. Morgan, T. van Ommen, M. A. J. Curran, J. Souney and K. J. Kreutz (2004), '700 year record of Southern Hemisphere extratropical climate variability', Annals of Glaciology 39, 127-132.

Mayewski, P. A., L. D. Meeker, S. I. Whitlow, M. S. Twickler, M. C. Morrison, P. Bloomfield, G. C. Bond, R. B. Alley, A. J. Gow, P. M. Grootes, D. Meese, M. Ram, K. C. Taylor and W. Wumkes (1994), 'Changes in atmospheric circulation and ocean ice cover over the North Atlantic during the last 41,000 years', Science 263, 1747-1751.

Mayewski, P. A., M. P. Meredith, C. P. Summerhayes, J. Turner, A. Worby, P. J. Barrett, G. Casassa, N. A. N. Bertler, T. Bracegirdle, A. C. NaveiraGarabato, D. Bromwich, H. Campbell, G. S. Hamilton, W. B. Lyons, K. A. Maasch, S. Aoki, C. Xiao and T. van Ommen (2009), 'State of the Antarctic and Southern Ocean climate system', Reviews of Geophysics 47, doi:10.1029/2007RG000231, in press.

Mayewski, P. A., M. S. Twickler, S. I. Whitlow, L. D. Meeker, Q. Yang, J. Thomas, K. J. Kreutz, P. M. Grootes, D. L. Morse, E. J. Steig, E. D. Waddington, E. S. Saltzman, P.-Y. Whung and K. C. Taylor (1996), 'Climate change during the last deglaciation in Antarctica', Science 272, 1636-1638.

McMorrow, A. J., M. A. J. Curran, T. D. van Ommen, V. I. Morgan and I. Allison (2002), 'Features of meteorological events preserved in a highresolution Law Dome (East Antarctica) snow pit', Annals of Glaciology 35, 463-470.

Meehl, G. A., J. W. Hurrel and H. van Loon (1998), 'A modulation of the mechanism of the semiannual oscillation in the Southern Hemisphere', Tellus 50A, 442-450.

Meyerson, E. A., P. A. Mayewski, K. J. Kreutz, L. D. Meeker, S. I. Whitlow and M. S. Twickler (2002), 'The polar expression of ENSO and sea-ice variability as recorded in a South Pole ice core', Annals of Glaciology $\mathbf{2 5}, 430-436$.

Mo, K. C. and M. Ghil (1987), 'Statistics and dynamics of persistent anomalies', Journal of the Atmospheric Sciences 44, 877-901.

Monaghan, A. J. and D. H. Bromwich (2008), 'Advances in describing recent Antarctic climate variablity', Bulletin of the American Meteorological Society 89, 1295-1306.

Monaghan, A. J., D. H. Bromwich, R. L. Fogt, S.-H. Wang, P. A. Mayewski, D. A. Dixon, A. Ekaykin, M. Frezzotti, I. Goodwin, E. Isaaksson, S. D. 
Kaspari, V. I. Morgan, H. Oerter, T. D. van Ommen, C. J. van der Veen and J. Wen (2006), 'Insignificant change in Antarctic snowfall since the International Geophysical Year', Science 313, 827-831.

Monaghan, A. J., D. H. Bromwich, W. Chapman and J. C. Comiso (2008), 'Recent variability and trends of antarctic nearsurface temperature', Journal of Geophysical Research 113, D04105, doi:10.1029/2007JD009094.

Mulvaney, R., D. Wagenbach and E. W. Wolff (1998), 'Postdepositional change in snowpack nitrate from observation of year-round nearsurface snow in coastal Antarctica', Journal of Geophysical Research 103(D9), 11021-11032.

Mulvaney, R. and E. W. Wolff (1994), 'Spatial variability of the major chemistry of the Antarctic ice sheet', Annals of Glaciology 20, 440-447.

Narcisi, B., J. R. Petit, B. Delmotte, I. Basile-Doelseh and V. Maggi (2005), 'Characteristics and sources of tephra layers in the EPICA-Dome C ice record (East Antarctica): implications for past atmospheric circulation and ice core stratigraphic correlations', Earth and Planetary Science Letters 239, 253-265.

Noone, D., J. Turner and R. Mulvaney (1999), 'Atmospheric signals and characteristics of accumulation in Dronning Maud Land, Antarctica', Journal of Geophysical Research 104(D16), 19191-19211.

Orr, A., D. Cresswell, G. J. Marshall, J. C. R. Hunt, J. Sommeria, C. G. Wang and M. Light (2004), 'A 'low level' explanation for the recent large warming trend over the western Antarctic Peninsula involving blocked winds and changes in zonal circulation', Geophysical Research Letters 31, L06204, doi:10.1029/2003GL019160.

Palmer, T. N. (1999), 'A nonlinear dynamical perspective on climate prediction', Journal of Climate 12, 575-591.

Park, Y., F. Roquet and F. Vivier (2004), 'Quasi-stationary ENSO wave signals versus the Antarctic Circumpolar Wave scenario', Geophysical Research Letters 31, L09315, doi:10.1029/2004GL019806.

Pasteur, E. C. and R. Mulvaney (1999), 'Laboratory study of the migration of methane sulphonate in firn', Journal of Glaciology 45, 214-218.

Pasteur, E. C. and R. Mulvaney (2000), 'Migration of methane sulphonate in Antarctic firn and ice', Journal of Geophysical Research 105(D9), 1152511534.

Peel, D. A. and R. Mulvaney (1992), 'Time-trends in the pattern of oceanatmosphere exchanges in an ice core from the Weddell Sea sector of Antarctica', Tellus 44B, 430-442.

Peixoto, J. P. and A. H. Oort (1992), Physics of Climate, American Institute of Physics, New York.

Petit, J. R., J. W. C. White, N. W. Young, J. Jouzel and Y. S. Korotkevich (1991), 'Deuterium excess in recent Antarctic snow', Journal of Geophysical Research 96(D3), 5113-5122.

Pezza, A. B., I. Simmonds and J. A. Renwick (2007), 'Southern Hemisphere cyclones and anticyclones: recent trends and links with decadal variability 
in the Pacific Ocean', International Journal of Climatology 27, 1403-1419.

Physick, W. L. (1981), 'Winter depression tracks and climatological jet streams in the Southern Hemisphere during the FGGE year', Quarterly Journal of the Royal Meteorological Society 107, 883-898.

Pittock, A. B. (1980), 'Patterns of climatic variation in Argentina and Chile - 1: precipitation, 1931-60', Monthly Weather Review 108, 1347-1361.

Power, S., T. Casey, C. Folland, A. Colman and V. Mehta (1999), 'Interdecadal modulation of the impact of ENSO on Australia', Climate Dynamics 15, 319-324.

Prospero, J. M., D. L. Savoie, E. S. Saltzman and R. Larsen (1991), 'Impact of oceanic sources of biogenic sulfur on sulfate aerosol concentrations at Mawson, Antarctica', Nature 350, 221-223.

Pudsey, C. J. and J. Evans (2001), 'First survey of Antarctic sub-ice shelf sediments reveals mid-holocene ice shelf retreat', Geology 29, 787-790.

Quinn, W. H. and V. T. Neal (1992), The historical record of El Niño events, in R. S. Bradley and P. D. Jones, eds, 'Climate since A.D. 1500', Routledge, London, pp. 623-648.

Rack, W. and H. Rott (2004), 'Pattern of retreat and disintegration of the Larsen B ice shelf, Antarctic Peninsula', Annals of Glaciology 39, 505510.

Rankin, A. M., E. W. Wolff and R. Mulvaney (2004), 'A reinterpretation of sea-salt records in Greenland and Antarctic ice cores?', Annals of Glaciology 39, 276282.

Rankin, A. M., E. W. Wolff and S. Martin (2002), 'Frost flowers: implications for tropospheric chemistry and ice core interpretation', Journal of Geophysical Research 107(D23), 4683, doi:10.1029/2002JD002492.

Reijmer, C. H. and M. R. van den Broeke (2001), 'Moisture source of precipitation in western Dronning Maud Land, Antarctica', Antarctic Science 13, 210-220.

Reijmer, C. H., M. R. van den Broeke and M. P. Scheele (2002), 'Air parcel trajectories and snowfall related in five deep drilling locations in Antarctica based on the ERA-15 dataset', Journal of Climate 15, 1957-1968.

Renwick, J. A. (2005), 'Persistent positive anomalies in the Southern Hemisphere circulation', Monthly Weather Review 133, 977988.

Reusch, D. B., B. C. Hewitson and R. B. Alley (2005), 'Towards ice-corebased synoptic reconstructions of west Antarctic climate with artificial neural networks', International Journal of Climatology 25, 581-610.

Reusch, D. B., P. A. Mayewski, S. I. Whitlow, I. I. Pittalwala and M. S. Twickler (1999), 'Spatial variability of climate and past atmospheric circulation patterns from central west Antarctic glaciochemistry', Journal of Geophysical Research 104(D6), 5985-6001.

Rogers, J. C. and H. van Loon (1982), 'Spatial variability of sea level pressure and $500 \mathrm{mb}$ height anomalies over the Southern Hemisphere', Monthly Weather Review 110, 13751392.

Roscoe, H. K., G. J. Marshall and J. C. King (2006), 'Low potential for stratospheric dynamical change to be implicated in the large winter warm- 
ing in the central Antarctic Peninsula', Quarterly Journal of the Royal Meteorological Society 132, 803-820.

Russell, A., G. R. McGregor and G. J. Marshall (2004), 'An examination of the precipitation delivery mechanisms for Dolleman Island, eastern Antarctic Peninsula', Tellus 56A, 501-513.

Russell, A., G. R. McGregor and G. J. Marshall (2006), '340 years of atmospheric circulation characteristics reconstructed from an eastern Antarctic Peninsula ice core', Geophysical Research Letters 33, L08702, doi:10.1029/2006GL025899.

Russell, A., G. R. McGregor and G. J. Marshall (2008), 'Eastern Antarctic Peninsula precipitation delivery mechanisms: process studies and back trajectory evaluation', Atmospheric Science Letters 9, 214-221.

Schlosser, E. (1999), 'Effects of seasonal variability of accumulation on yearly mean $\delta^{18} \mathrm{O}$ values in Antarctic snow', Journal of Glaciology 45, 463-468.

Schlosser, E., H. Oerter, V. Masson-Delmotte and C. Reijmer (2008), 'Effects of seasonal variability of accumulation on yearly mean $\delta^{18} \mathrm{O}$ values in Antarctic snow', Journal of Glaciology 54, 117-124.

Schneider, D. P. and D. C. Noone (2007), 'Spatial covariance of water isotopes in ice cores during 20th century climate change', Journal of Geophysical Research 112, doi:10.1029/2007JD008652.

Schneider, D. P., E. J. Steig and J. C. Comiso (2004), 'Recent climate variability in Antarctica from satellite-derived temperature data', Journal of Climate 17, 1569-1583.

Schneider, D. P. and E. Steig (2008), 'Ice cores record significant 1940s Antarctic warmth related to tropical climate variability', Proceedings of the National Academy Of Sciences of the United States of America 105, 12154-12158.

Schneider, D. P., E. Steig, T. D. van Ommen, D. A. Dixon, P. Mayewski, J. M. Jones and C. M. Bitz (2006), 'Antarctic temperatures over the past two centuries from ice cores', Geophysical Research Letters 33, Art. No. L16707.

Sexton, D. M. H. (2001), 'The effect of stratospheric ozone depletion on the phase of the Antarctic Oscillation', Geophysical Research Letters 28, 3697-3700.

Shepherd, A., D. Wingham, T. Payne and P. Skvarca (2003), 'Larsen ice shelf has progressively thinned', Science 302, 856-859.

Simmonds, I. H. and K. Keay (2000a), 'Mean Southern Hemisphere extratropical cyclone behaviour in the 40-year NCEP-NCAR reanalysis', Journal of Climate 13, 873-885.

Simmonds, I. H. and K. Keay (2000b), 'Variability of Southern Hemisphere extratropical cyclone behaviour, 1958-97', Journal of Climate 13, 550561.

Simmonds, I. H., K. Keay and E.-P. Lim (2003), 'Synoptic activity in the seas around Antarctica', Monthly Weather Review 131, 272-288. 
Sinclair, M. R. (1994), 'An objective cyclone climatology for the Southern Hemisphere', Monthly Weather Review 122, 2239-2256.

Sinclair, M. R. (1995), 'A climatology of cyclogenesis for the Southern Hemisphere', Monthly Weather Review 123, 1601-1619.

Sinclair, M. R. (1996), 'A climatology of anticyclones and blocking for the Southern Hemisphere', Monthly Weather Review 124, 245-263.

Smith, S. R. and C. R. Stearns (1993), 'Antarctic pressure and temperature anomalies surrounding the minimum in the Southern Oscillation index', Journal of Geophysical Research 98(D7), 13071-13083.

Souney, J. M., P. A. Mayewski, I. D. Goodwin, L. D. Meeker, V. Morgan, M. A. J. Curran, T. D. van Ommen and A. S. Palmer (2002), 'A 700-year record of atmospheric circulation developed from the Law Dome ice core, east Antarctica', Journal of Geophysical Research 107(D22), 10.1029/2002JD002104.

Steig, E. J., D. P. Schneider, S. D. Rutherford, M. E. Mann, J. C. Comiso and D. T. Shindell (2009), 'Warming of the Antarctic ice-sheet surface since the 1957 International Geophysical Year', Nature 457, 459-463.

Streten, N. A. and A. J. Troup (1973), 'A synoptic climatology of satellite observed cloud vortices over the Southern Hemisphere', Quarterly Journal of the Royal Meteorological Society 99, 56-72.

Taljaard, J. J. (1967), 'Development, distribution and movement of cyclones and anticyclones in the Southern Hemisphere during the IGY', Journal of Applied Meteorology 6, 973-987.

Thomas, E. R., G. J. Marshall and J. R. McConnell (2008), 'A doubling in snow accumulation in the western Antarctic Peninsula since 1850', Geophysical Research Letters 35, L01706, doi:10.1029/2007GL032529.

Thompson, D. W. J. and J. M. Wallace (2000), 'Annular modes of extratropical circulation. Part I: month-to-month variability', Journal of Climate 13, 1000-1016.

Thompson, D. W. J., J. M. Wallace and G. C. Hegerl (2000), 'Annular modes in the extratropical circulation. Part II: trends', Journal of Climate 13, 1018-1036.

Thompson, D. W. J. and S. Solomon (2002), 'Interpretation of recent Southern Hemisphere climate change', Science 296, 895-899.

Tietäväinen, H. and T. Vihma (2008), 'Atmospheric moisture budget over Antarctica and the Southern Ocean on the basis of ERA-40 reanalysis', International Journal of Climatology 28, 1977-1995.

Trenberth, K. E. (1984), 'Interannual variability of the SouthernHemisphere circulation-representativeness of the year of the Global Weather Experiment', Monthly Weather Review 112, 108-123.

Trenberth, K. E. (1995), 'Atmospheric circulation climate changes', Climatic Change 31, 427-453.

Trenberth, K. E. (1997), 'The definition of El Niño', Bulletin of the American Meteorological Society 78, 2771-2777.

Trenberth, K. E. and D. P. Stepaniak (2003a), 'Covariability of components of poleward atmospheric energy transports on seasonal and interannual 
timescales', Journal of Climate 16, 3691-3705.

Trenberth, K. E. and D. P. Stepaniak (2003b), 'Seamless poleward atmospheric energy transports and implications for the Hadley Circulation', Journal of Climate 16, 3706-3722.

Trenberth, K. E., D. P. Stepaniak and L. Smith (2005), 'Interannual variability of the patterns of atmospheric mass distribution', Journal of Climate 18, 28122825.

Trenberth, K. E., P. D. Jones, P. Ambenje, R. Bojariu, D. Easterling, A. Klein Tank, D. Parker, F. Rahimzadeh, J. A. Renwick, M. Rusticucci, B. Soden and P. Zhai (2007), Observations: Surface and atmospheric climate change, in S. Solomon, D. Qin, M. Manning, Z. Chen, M. Marquis, K. B. Averyt, M. Tignor and H. L. Miller, eds, 'Climate Change 2007: The Physical Science Basis. Contribution of Working Group I to the Fourth Assessment Report of the Intergovernmental Panel on Climate Change', Cambridge University Press, Cambridge, United Kingdom and New York, NY, USA, pp. 235-336.

Turner, J. (2004), 'The El Niño-Southern Oscillation and the Antarctic', International Journal of Climatology 24, 1-31.

Turner, J., G. J. Marshall and T. Lachlan-Cope (1998), 'Analysis of synoptic-scale low pressure systems within the Antarctic Peninsula sector of the circumpolar trough', International Journal of Climatology 18, 253280 .

Turner, J., J. C. King, T. Lachlan-Cope and P. D. Jones (2002), 'Recent temperature trends in the Antarctic', Nature 418, 291-292.

Turner, J., S. R. Colwell, G. J. Marshall, T. Lachlan-Cope, A. M. Carleton, P. D. Jones, V. Lagun, P. A. Reid and S. Iagovkina (2005), 'Antarctic climate change during the last 50 years', International Journal of Climatology 25, 279-294.

Turner, J., T. A. Lachlan-Cope, S. Colwell, G. J. Marshall and W. M. Connolley (2006a), 'Significant warming of the Antarctic winter troposphere', Science 311, 1914-1917.

Turner, J., T. Lachlan-Cope, J. P. Thomas and S. R. Colwell (1995), 'The synoptic origins of precipitation over the Antarctic Peninsula', Antarctic Science 7, 327-337.

Turner, J., W. M. Connolley, T. Lachlan-Cope and G. J. Marshall (2006b), 'The performance of the Hadley Centre climate model (HadCM3) in high southern latitudes', International Journal of Climatology 26, 91-112.

van den Broeke, M. R. (1998a), 'The semi-annual oscillation and Antarctic climate. Part 1: influence on near surface temperatures (1957-79)', Antarctic Science 10, 175-183.

van den Broeke, M. R. (1998b), 'The semi-annual oscillation and Antarctic climate. Part 2: recent changes', Antarctic Science 10, 184-191.

van den Broeke, M. R. (2005), 'Strong surface melting preceded collapse of Antarctic Peninsula ice shelf', Geophysical Research Letters 32, L12815, doi:10.1029/2005GL023247. 
van den Broeke, M. R. and N. P. M. van Lipzig (2003), 'Factors controlling the near-surface wind field in Antarctica', Monthly Weather Review 131, 733-743.

van Lipzig, N. P. M., E. van Meijgaard and J. Oerlemans (1999), 'Evaluation of a regional atmospheric model using measurements of surface heat exchange processes from a site in Antarctica', Monthly Weather Review 127, 1994-2011.

van Lipzig, N. P. M., G. J. Marshall, A. Orr and J. C. King (2008), 'The relationship between the Southern Hemisphere Annular Mode and Antarctic Peninsula summer temperatures: Analysis of a high-resolution model climatology', Journal of Climate 21, 1649-1668.

van Loon, H. (1965), 'A climatological study of the atmospheric circulation in the Southern Hemisphere during the IGY. Part I: 1 July 1957 - 31 March 1958', Journal of Applied Meteorology 4, 479-491.

van Loon, H. (1967), 'The half-yearly oscillations in middle and high southern latitudes and the Coreless Winter', Journal of the Atmospheric Sciences 24, 472-486.

Vaughan, D. G., G. J. Marshall, W. M. Connolley, C. L. Parkinson, R. Mulvaney, D. A. Hodgsen, J. C. King, C. J. Pudsey and J. Turner (2003), 'Recent rapid regional climate warming on the Antarctic Peninsula', Climatic Change 60, 243-274.

Vaughan, D. G., G. J. Marshall, W. M. Connolley, J. C. King and R. Mulvaney (2001), 'Devil in the detail', Science 293, 1777-1779.

Villalba, R., E. R. Cook, R. D. DArrigo, G. C. Jacoby, P. D. Jones, M. S. Salinger and J. Palmer (1997), 'Sea-level pressure variability around Antarctica since A.D. 1750 inferred from sub-Antarctic tree-ring records', Climate Dynamics 13, 375390.

Vincent, D. G. (1994), 'The South Pacific Convergence Zone (SPCZ) : a review', Monthly Weather Review 122, 1949-1970.

Wagenbach, D., F. Ducroz, R. Mulvaney, K. Keck, A. Minikin, M. R. Legrand, J. S. Hall and E. W. Wolff (1998), 'Sea-salt aerosol in coastal Antarctic regions', Journal of Geophysical Research 103, 10961-10974.

Walker, G. T. (1928), 'World weather', Quarterly Journal of the Royal Meteorological Society 54, 79-87.

White, W. B. and R. G. Peterson (1996), 'An Antarctic circumpolar wave in surface pressure, wind and sea-ice extent', Nature 380, 699-702.

Whitlow, S., P. A. Mayewski and J. E. Dibb (1992), 'A comparison of major chemical species seasonal concentration and accumulation at the South Pole and Summit, Greenland', Atmospheric Environment 26A, 20452054.

Wolff, E. W., A. M. Rankin and R. Rthlisberger (2003), 'An ice core indicator of Antarctic sea ice production?', Geophysical Research Letters 30, 2158, doi: 10.1029/2003GL018454.

Xiao, C. D., P. A. Mayewski, D. H. Qin, Z. Q. Li, M. J. Zhang and Y. P. Yan (2004), 'Sea level pressure variability over the southern Indian Ocean inferred from a glaciochemical record in Princess Elizabeth Land, 
east Antarctica', Journal of Geophysical Research 109(D16), D16101, doi:10.1029/2003JD004065.

Yuan, X. and D. G. Martinson (2001), 'The Antarctic dipole and its predictability', Geophysical Research Letters 28, 3609-3612. 